\title{
رسمُ الهمزة وأثرُه في القراعات القرآنيّة دراسة في البنية والدلالة
}

1. م. دـ عصام كاظم الغالبيّ

جامعة الكوفة
1 .م ـد ميثم مهذيّ الحمّاميّ

جامعة الكوفة ملثة

بسم الله الرحمن الرحيم

الحمد لله رب العالمين والصلاة والسلام على سيدنا محمد المبعوث رحمة للعالمين وعلى آله

الطيبين الطاهرين وصحبه المنتجبين ، وبعد :

فتُعدّ القراءات القرآنيّة من الموضوعات التي شغلت كثيرا من الباحثين قديما وحديثا فاحتلت مساحة

واسعة في الفكر والدراسة لاتصالها بالقرآن اتصالا مباشرا ، ولعل السبب الرئيس الذي حدانا لجعل القراءات

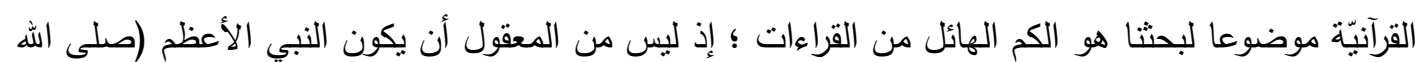

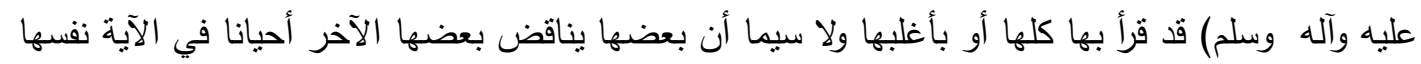

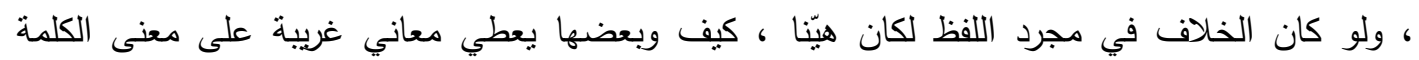

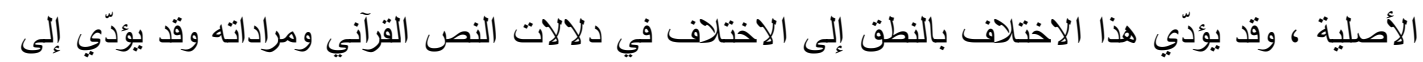

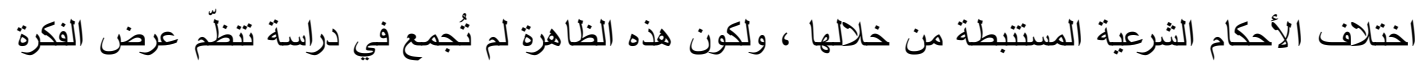
وتقدم التفسير العلمي لها وجدنا من المناسب أن نقوم بجمعها ودراستها وقد أسميناها بـ :(( رسم الهمزة وأثره في القراعات القرآنية ، دراسة في البنية والدلالة )).

وقد ذكر العلماء أسبابا كثيرة لاختلاف القراءات لعل أهمها طبيعة الكتابة العربية والرسم القرآنيّ

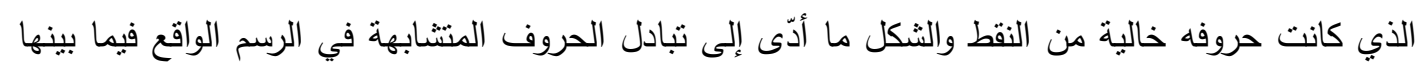

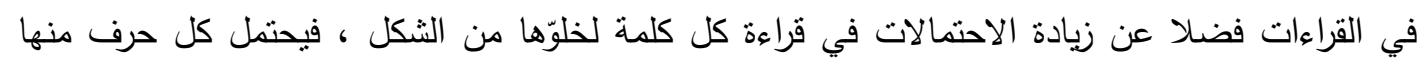

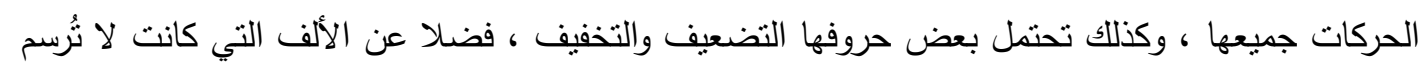

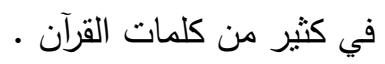




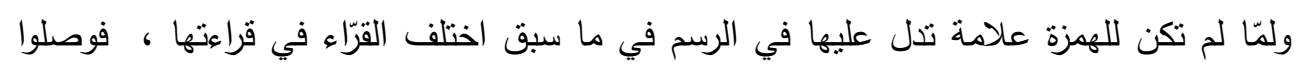

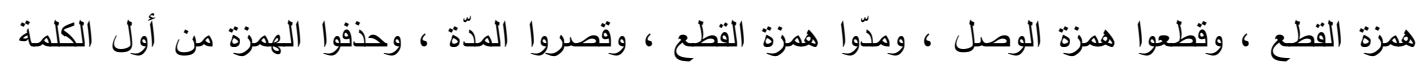

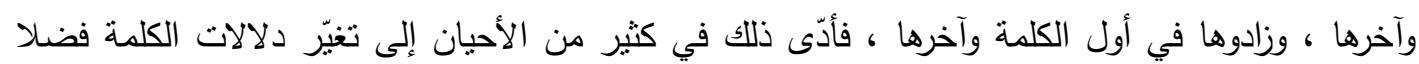

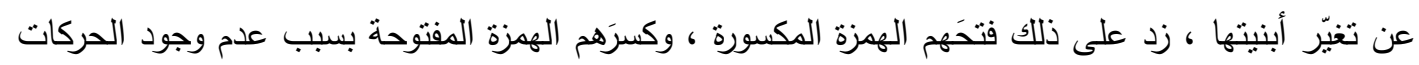

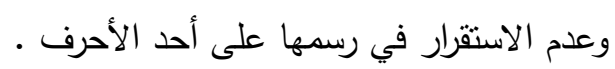

وإذا كان سببُ جواز القراءة ببعض القراءات مقصورًا على السعة عند الناس والتسهيل عليهم فلا

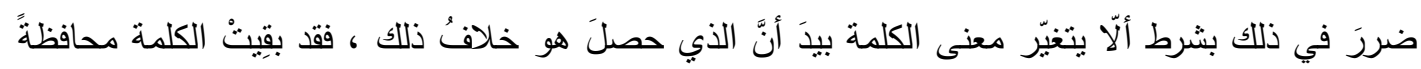

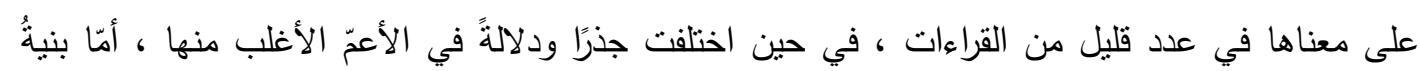

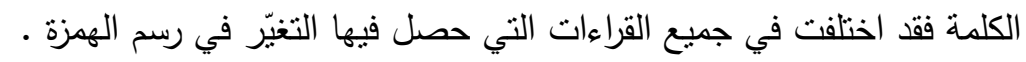

ولعلّ من أهمّ أهداف البحث هو النتبيه على خطر إطلاق النسامح في القراءات القرآنية إذا كانت

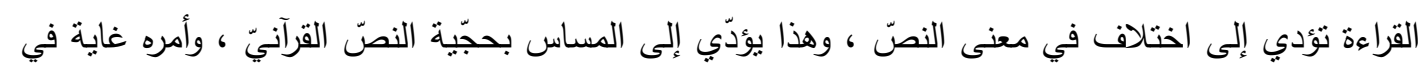

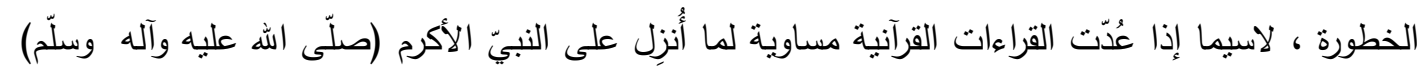

وقد اقتضت طبيعة البحث أن يُقسَّم على تمهيد وأربعة مباحث ، نتاول البحث في التمهيد الهمزة

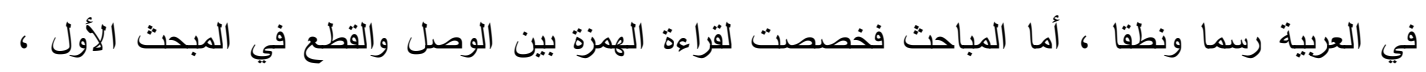

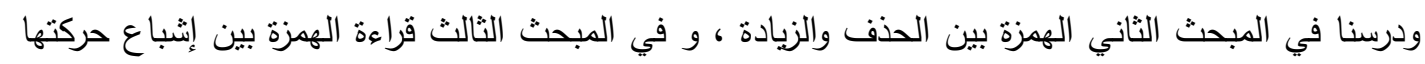

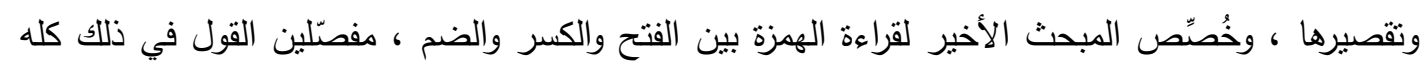

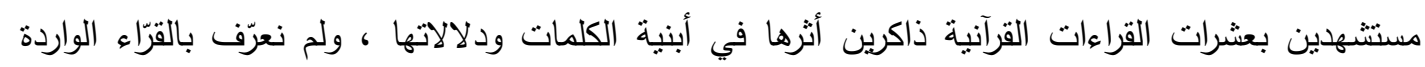

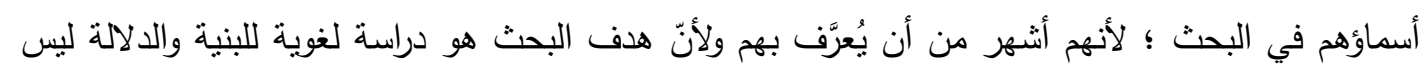

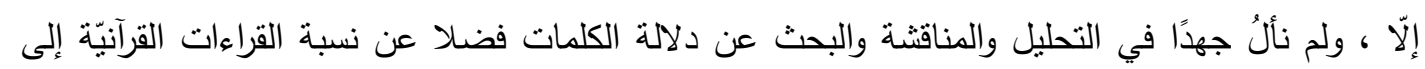

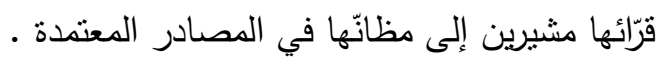




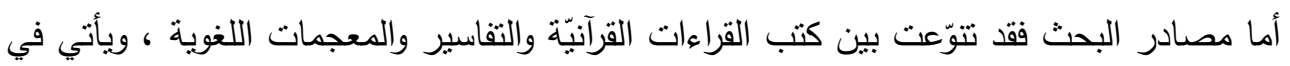
طليعة هذه المصادر كتاب المُحتسب لابن جني (ت392هـ) الذي اعتمدنا عليه في جرد القراءات القرآنيّة

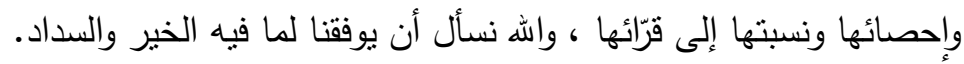

$$
\text { الباحثان }
$$

\section{التمهيا}

\section{الههزة في العربية رسمًا ونطقًا}

في الحديث عن رسم الهمزة جانبان ، أحدُهما يتعلق بتاريخ اللغة العربية ولهجاتها ، والآخر يُعنى العي

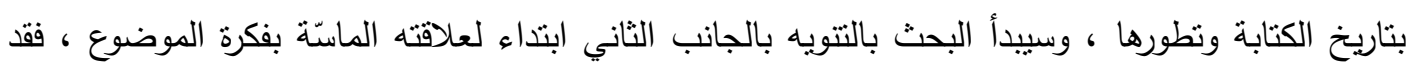

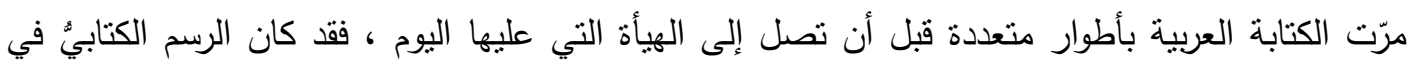

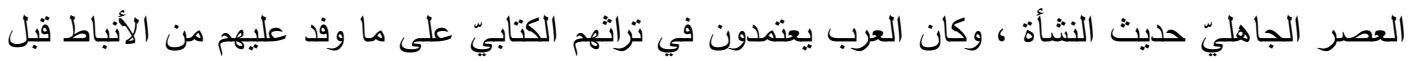

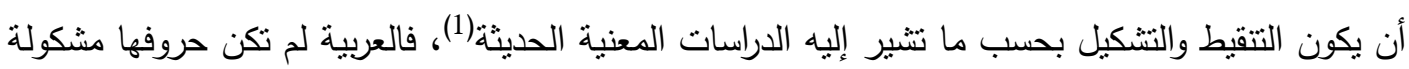

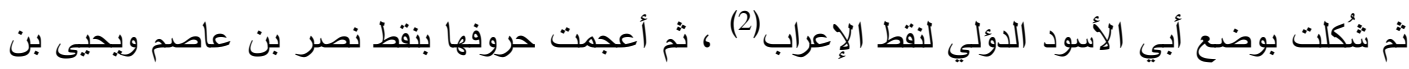
يعمر (3)، ولم تكن مهموزة ثم همزت بوضع الخليل لصورة الهمزة على شكل عين صغيرة ، إذ كان الخليل

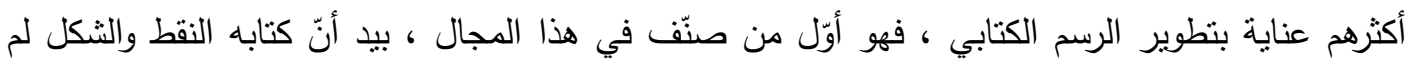

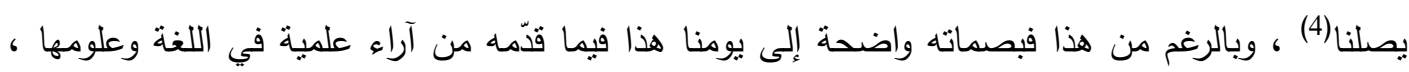

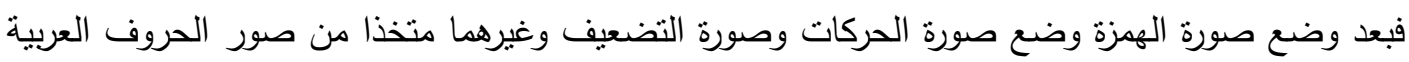
معينا لذلك (5).

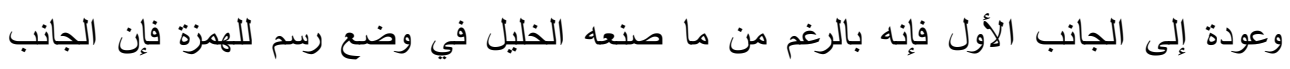

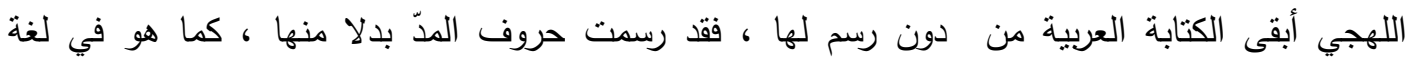

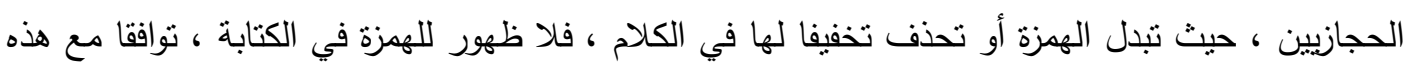

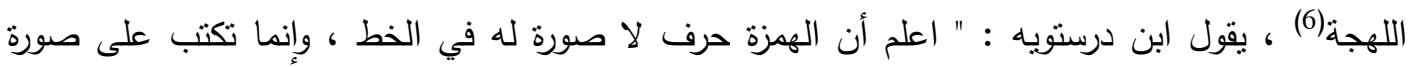

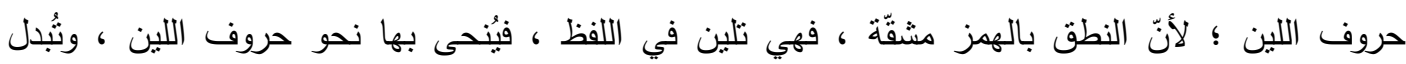




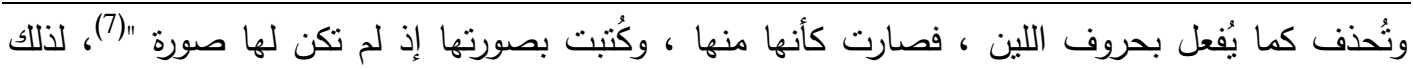

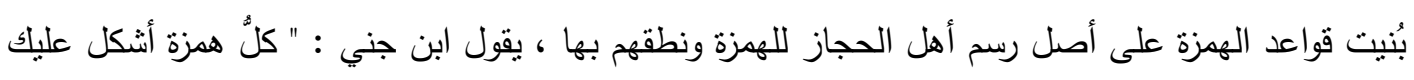

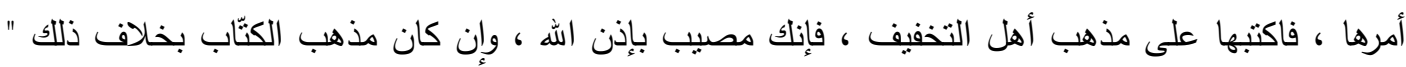

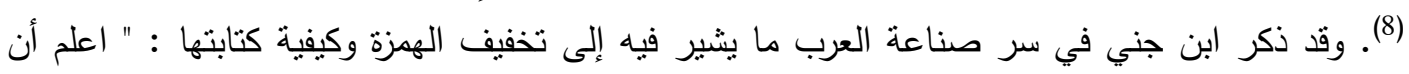

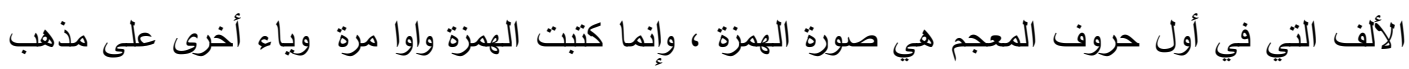

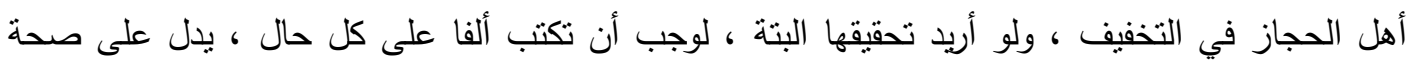

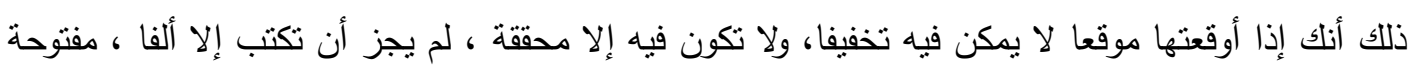

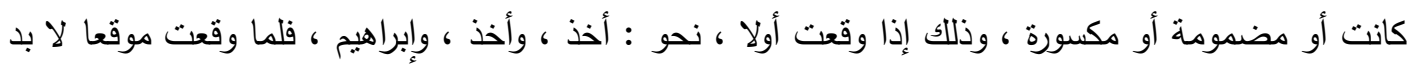

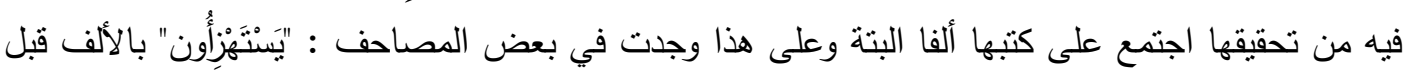

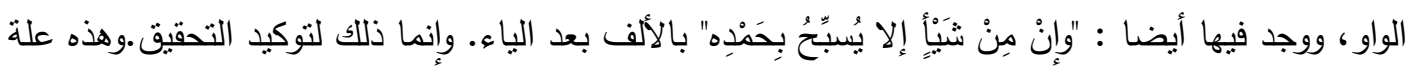

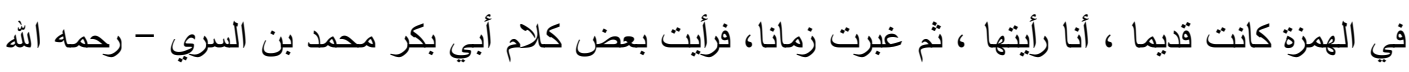

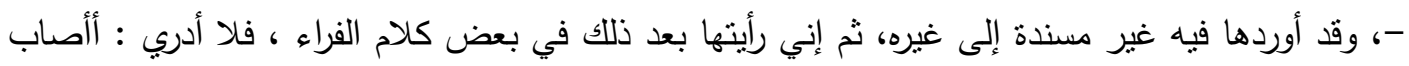

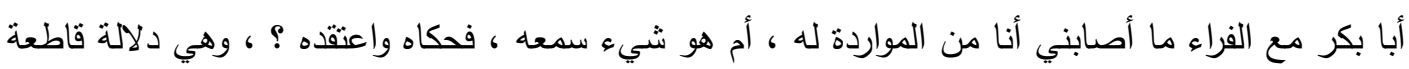

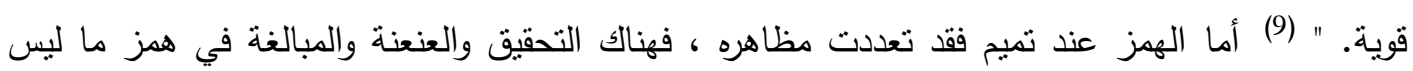
بمهوز (10) بمهن.

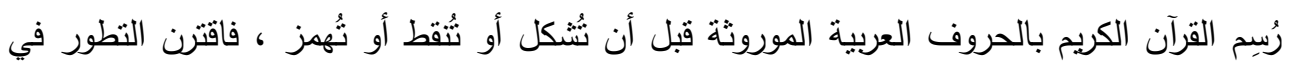

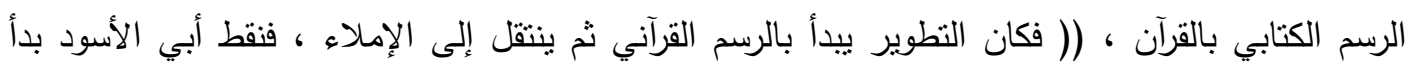

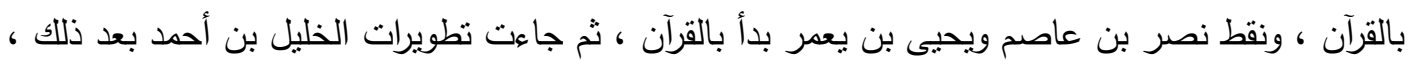

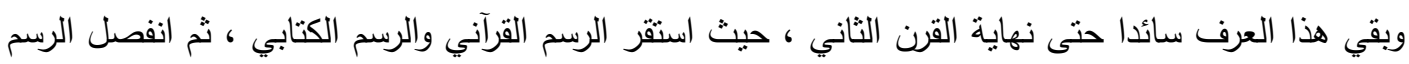
القرآني عن الرسم الكتابي ، وأصبح لدينا رسمان )( ل) (11).

لقد كان صوت الهمزة عند العرب من أكثر مظاهر التعدد اللهجي ، لكن بفضل القرآن استقرّ هذا

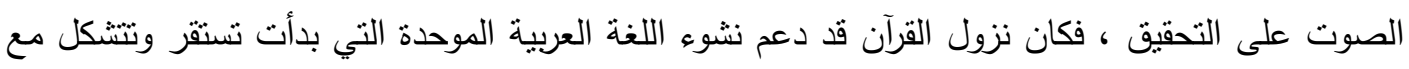

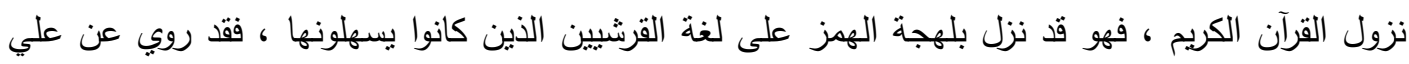


بن أبي طالب عليه السلام " نزل القرآن بلسان قريش ، وليسوا بأصحاب نبر ، ولولا أن جبرائيل عليه

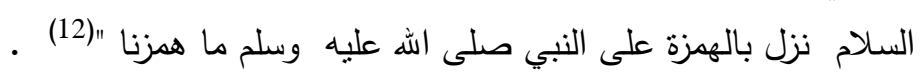

لكن انتقل الأمر بعد ذلك من التحقيق إلى النسامح بالهمز ، فنتوع النطق بين الهمز وبين التسهيل

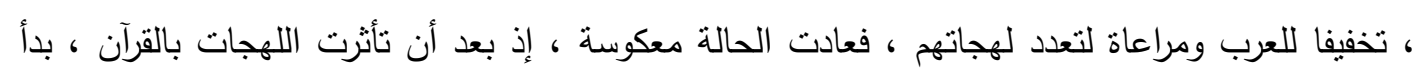

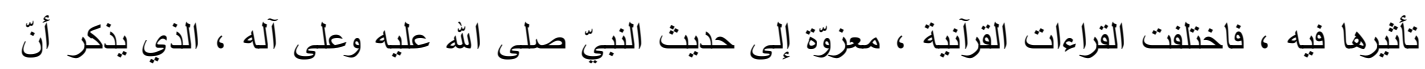

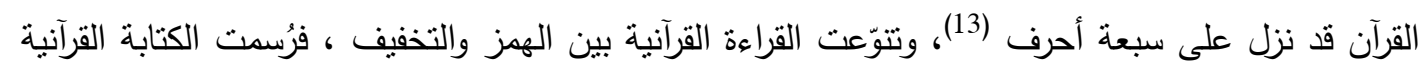
بالوجهين (14).

وليت الأمر قد بقي عند هذا الحد ، فقد بالغ بعض القرّاء بهمز ما لم يُهمز أصلا ، فقد قُرِئ في

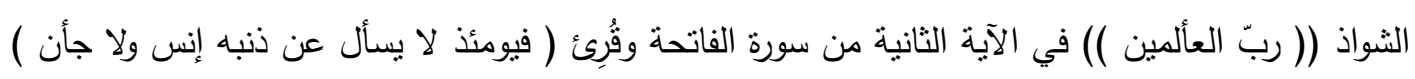

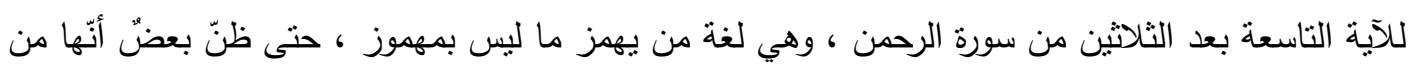

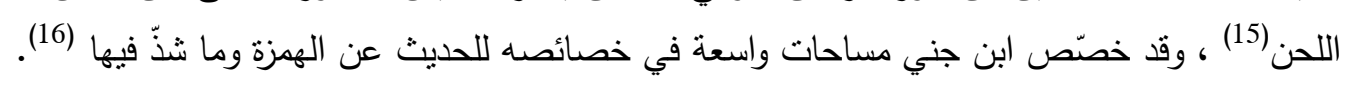
من هنا كان لزاما أن نستقري القراءات القرآنية التي تتوعت في صوت الهمزة بسبب اختلاف رسم

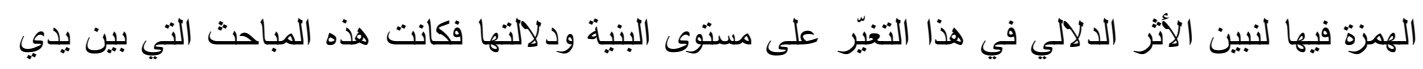

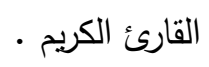




\section{المبحث الأول}

مجلــــة كليـــة التربيـــة

\section{قراءة الهمزة بين الوصل والقطع}

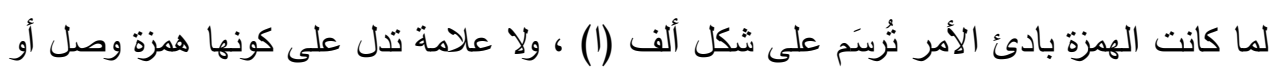

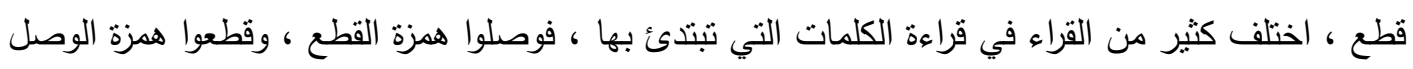

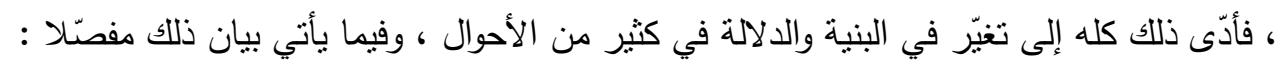

أولا : وصل همزة القطع : n

أدّى وصل همزة القطع في القراءات القرآنية إلى تغيّر في أبنية الاسم ودلالته ، وإلى تغيّر في أبنية

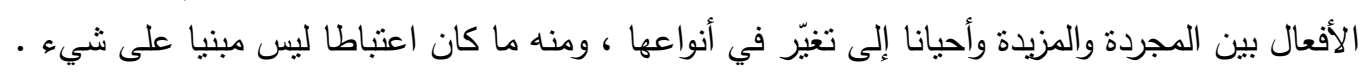

\section{1. تغيّر بنية الفعل ودلالته :}

فمن أمثلة وصل الهمزة وتغيّر بنية الفعل ودلالته ما ورد في قراءة الأعرج وأبي رجاء وعاصم

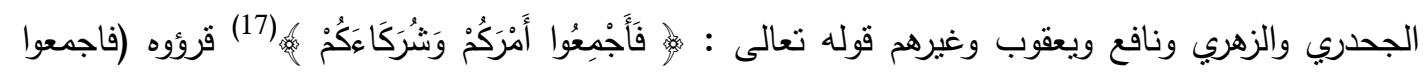

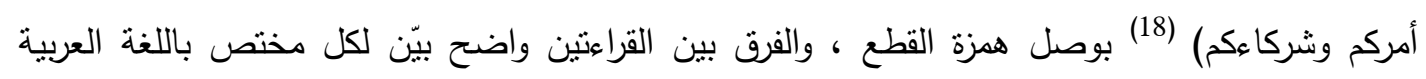

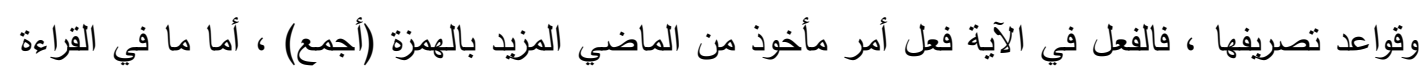

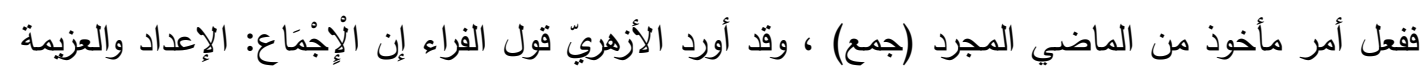
على الأْمَر (19).

وجاء في المخصنص " فأما قوله فأجمعوا أمرَكم وشُركاءَكم إِنََّا أَرَادَ فأجمِعوا أمرَكم واجمِعوا

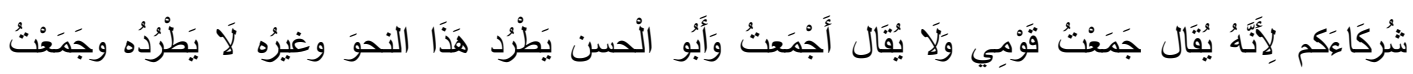

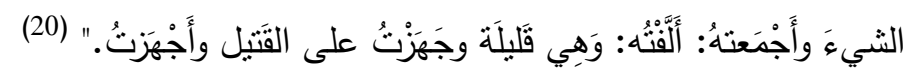


ومن أمتلة ما أدّى إلى التغيّر في نوع الفعل قراءة ابن عباس ومجاهد وقتادة وغيرهم قوله نعالى :

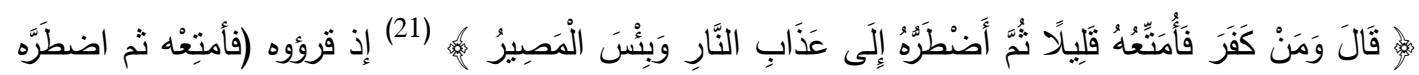

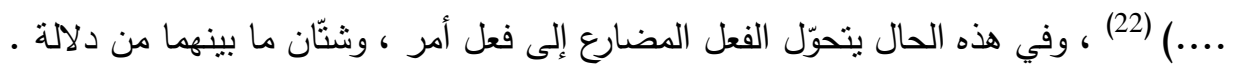

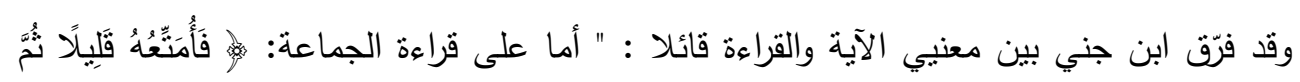

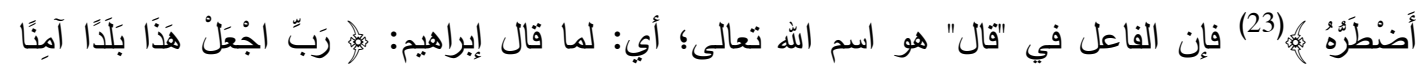

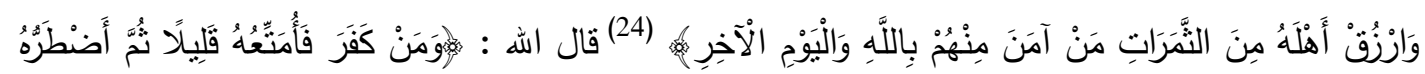

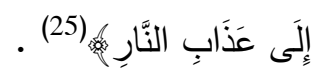

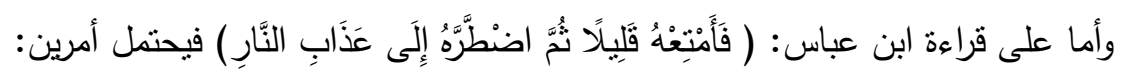

أحدهما: وهو الظاهر، أن يكون الفاعل في "قال" ضمير إبراهيم عليه السلام؛ أي: قال إبراهيم أيضًا: ومن

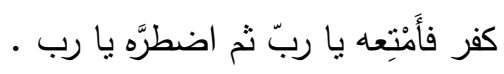
وحَسُنَ على هذا إعادة "قال" لأمرين:

أحدهما: طول الكلام، فلما تباعد آخره من أوله أُعيدت "قال" لبُعْدها، كما قد يجوز مع طول الكلام ما لا يحوز مع قصره.

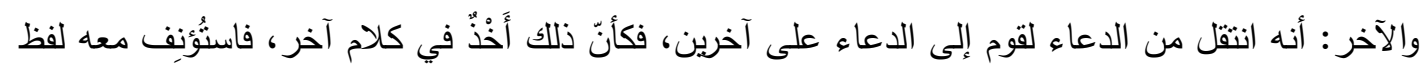

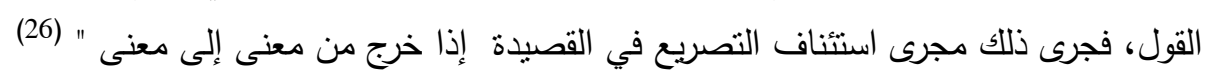

\section{3.}

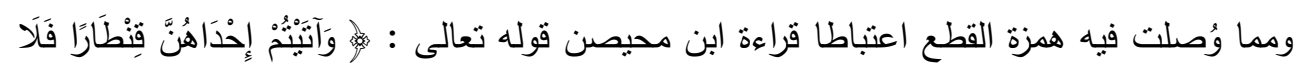

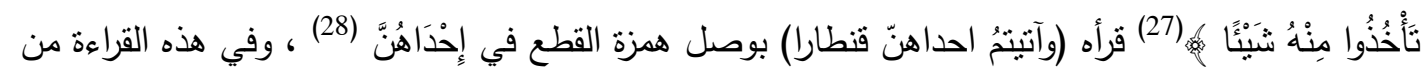

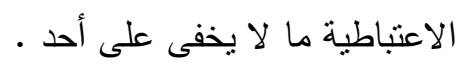


وبعد متابعة عدد من القراءات التي وُصِلت فيها همزة القطع وجد أن القارئ ابن محيصن يكاد

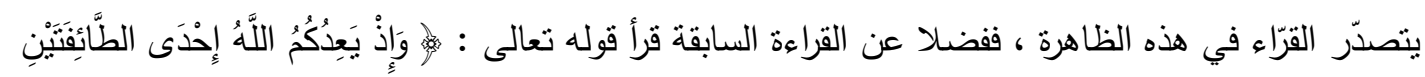

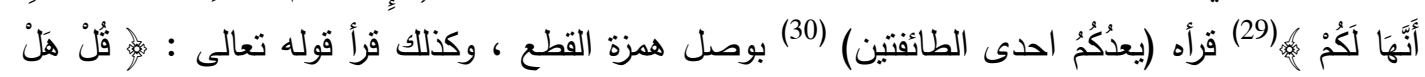

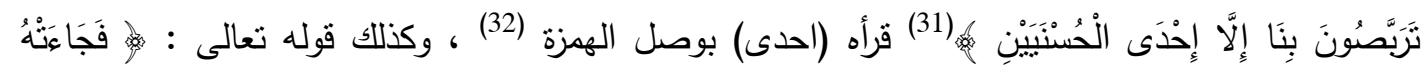

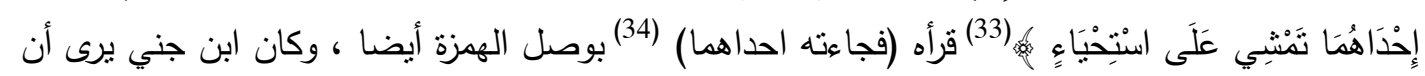
الوصل في هذه المواضع ضعيف وأنه إنما يجوز في الثعر لا في التنزيل (35).

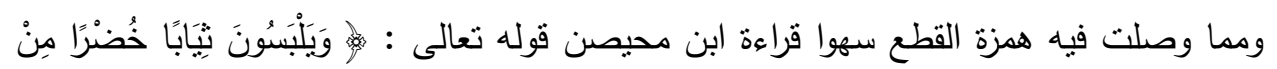

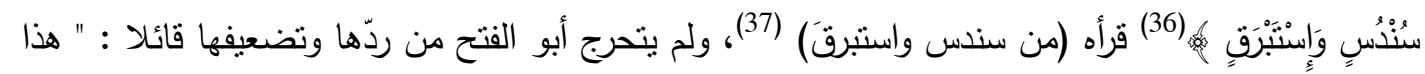

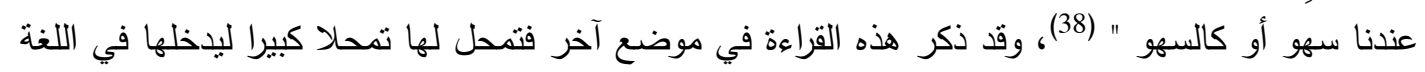

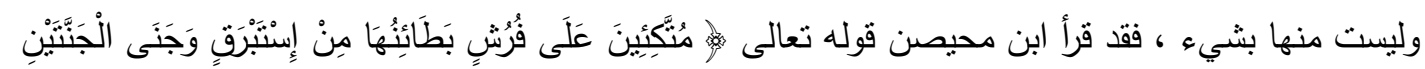

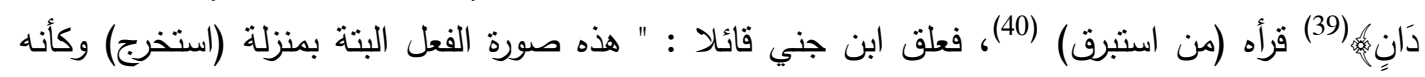

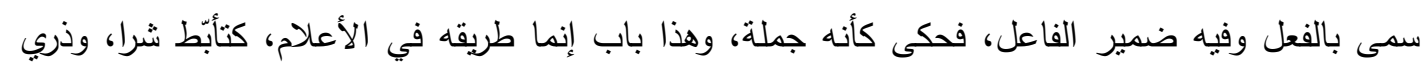

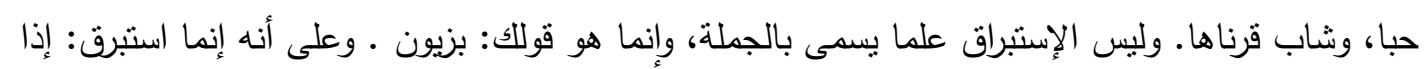

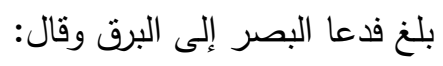

تنتبرق الأفق الأقصى إذا ابتست ... لاح السيوف سوى أغمادها القضب

[هذا إن شَُت قلت: معناه تسنبرق أبصار أهل الأفق وإن شئت قلت: ثبرقه، أي: تأتي بالبرق منه] " (41)

\section{ثانيا : قطع همزة الوصل :}

مما أدّى إليه قطع همزة الوصل في القراءات القرآنية ثلاثة أهور : 


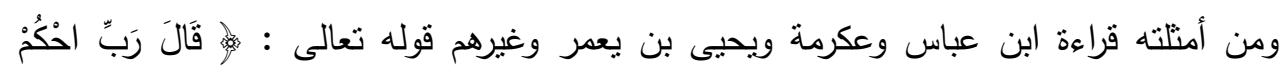

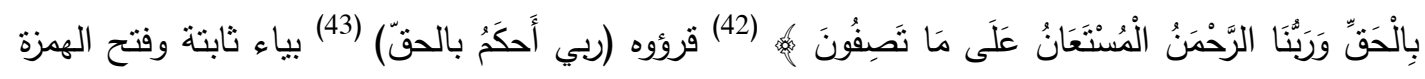

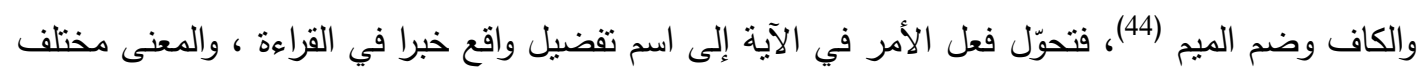

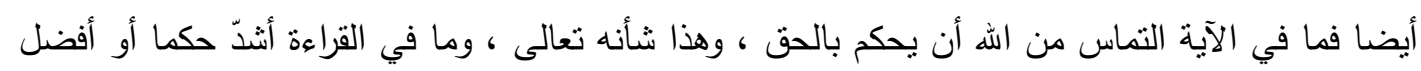
حكما أو أقوى حكما ف في الابة النما

\section{2.}

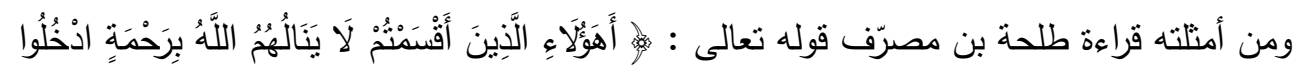

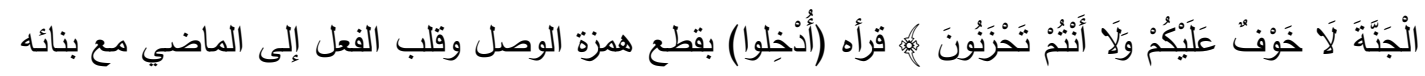

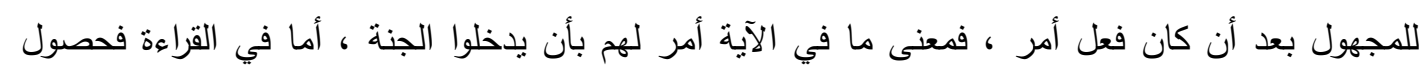

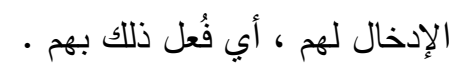

\section{3. ت تغيّر في بنية الفعل من المجرّد إلى المزيد :}

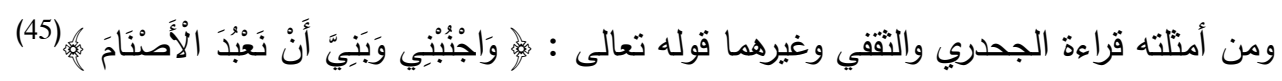

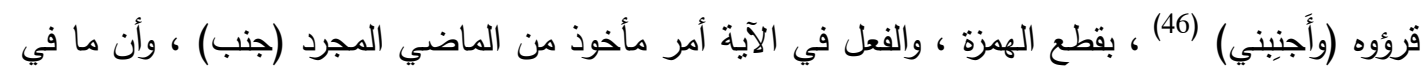

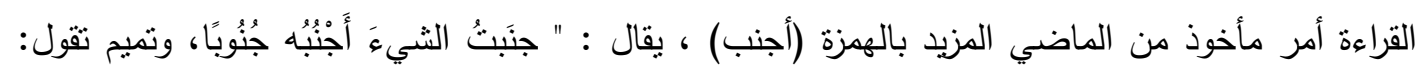

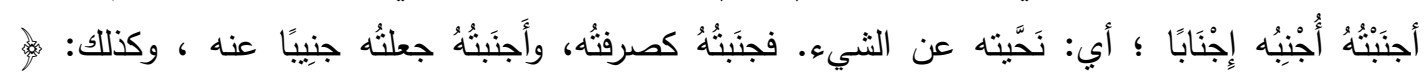

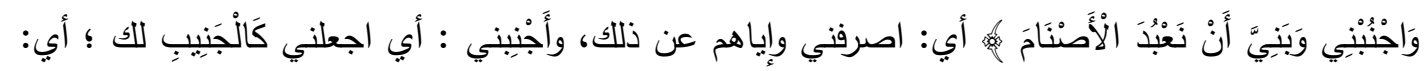

المنقاد معك عنها "(47). 


\section{قراءة الهمزة بين الحذف والزيادة}

حُذفت الهمزة في عدد من القراءات القرآنية وزيدت في عدد آخر ، وقد يكون السبب راجعا إلى أن

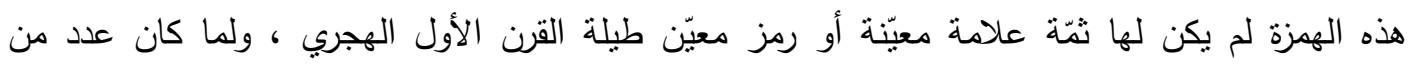

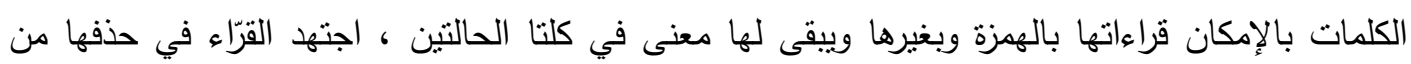

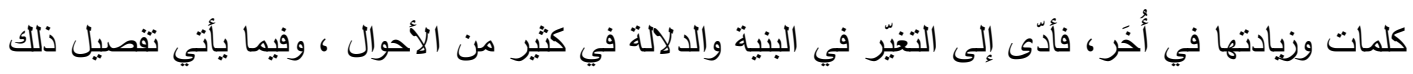
بالأمثلة :

أولا : حذف الهمزة : n

كثرت مواضع حذف الهمزة في القراءات القرآنية فربت على العثرين موضعا ، وذلك على نوعين حذف الهمزة من بداية الكلمة ، وحذف الهمزة من آخرها :

1 _ عذف الهمزة من بداية الكلمة : _ _

وأكثر ما كان ذلك في همزة الاستفهام السابقة لكلمة معيّنة ؛ إذ حذفها عدد من القرّاء وقرؤوا بلا

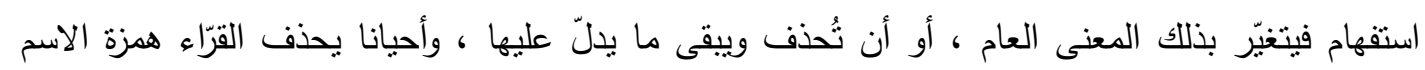

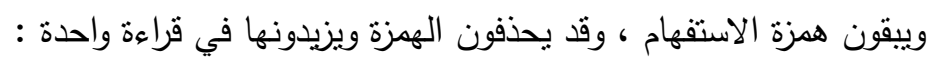

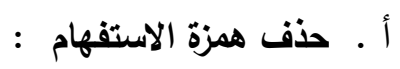

حذفت همزة الاستفهام في عدد من القراءات ، فضاع بذلك المعنى العام تارة ، وبقي ما يدلّ عليها

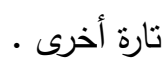

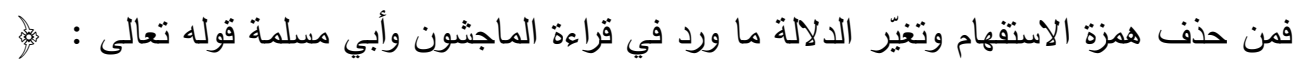

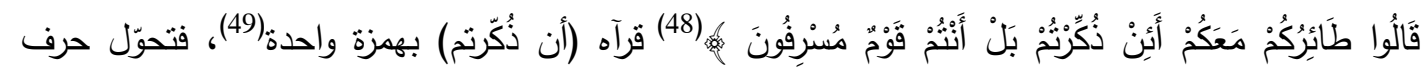

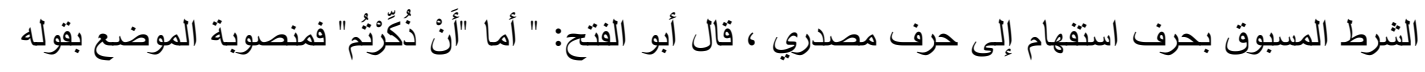




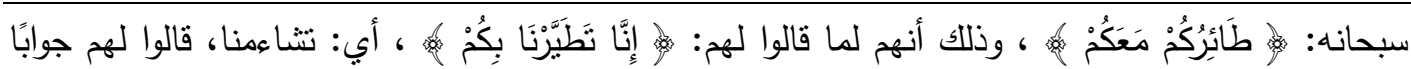

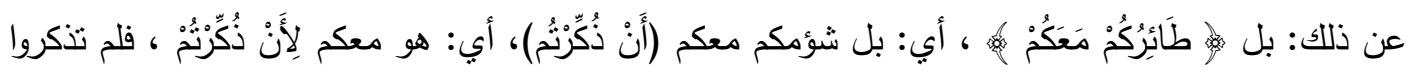

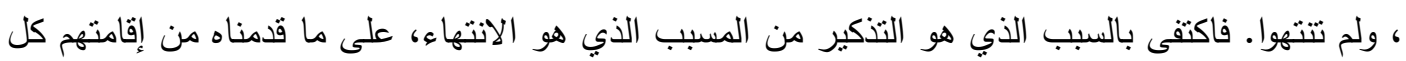

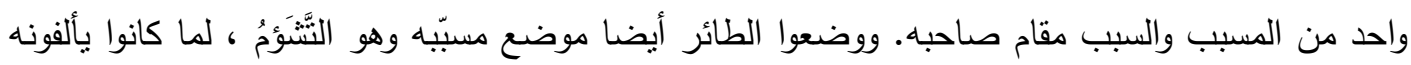

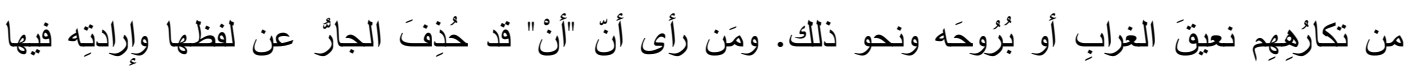
مجرورةً رأى ذلك هنا فيها، وهو الخليل ".

وكذلك ما ورد في قراءة الحسن وأبي الأسود والجحدري وابن عامر وحفص ورويس ونصر بن

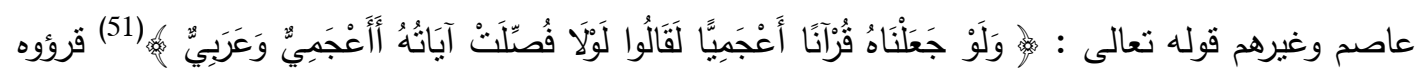

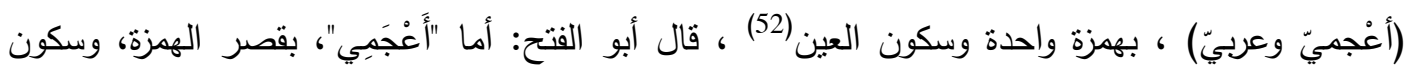

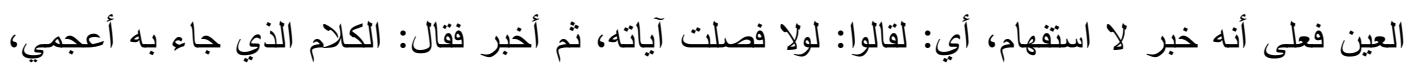

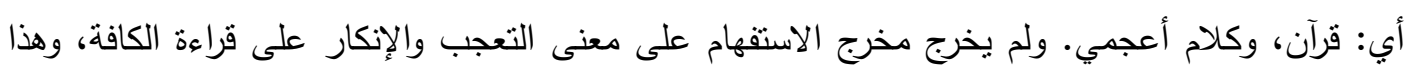

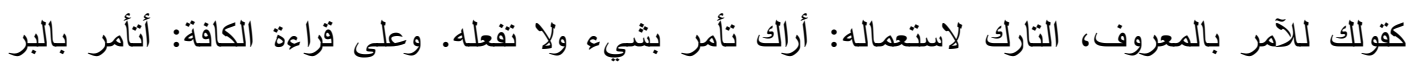
ونتركه؟."(53) بلاك

ومن حذف همزة الاستقهام وبقاء ما يدل عليها ما ورد في قراءة ابن كثثر والزهري وابن محيصن قوله

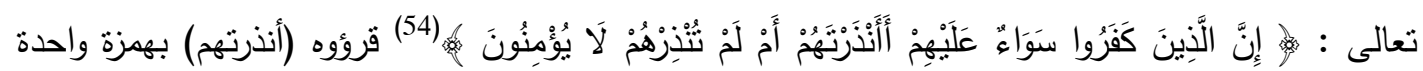

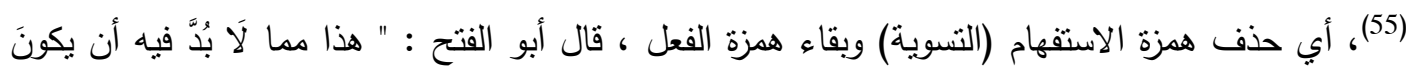

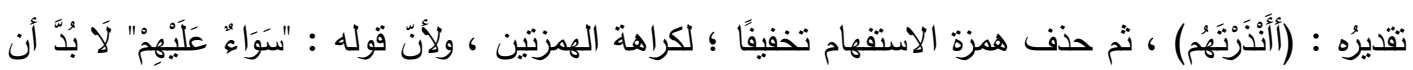

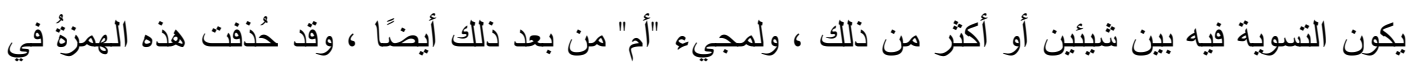
غير موضع من هذا الضرب، قال:

فأصبحتُ فيهم آنًا لا كمعشٍ ... أنوني فقالوا : مِن ربيعة أم مضر؟ فيمن قال: أم ؛ أي: أمن ربيعة أم مضر ؟ " (56) . ومن أبيات الكتاب: 
لعمرك ما أدري وإن كنت داريا ... شعيثُ ابن سهم أم شعيث ابن مِنْقَر (57) ملهُ

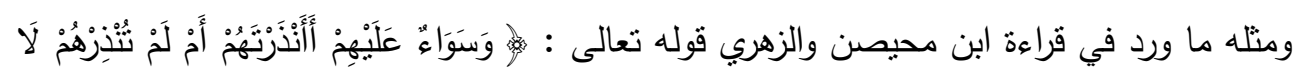

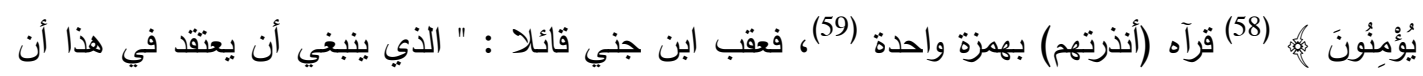

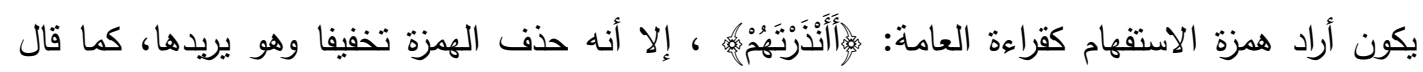

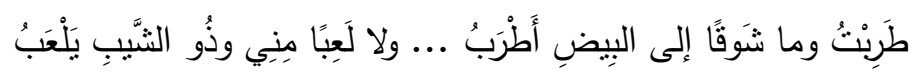
قالوا : معناه : أو ذو الثنيب يلعب ؟ تتاكُرًا لذلك، وتتعجًُا.....

ويدل على إرادة هذه القراءة الهمزة وأنها إنما حذفت لما ذكرنا بقاء "أم" بعدها، ولو أراد الخبر لقال :

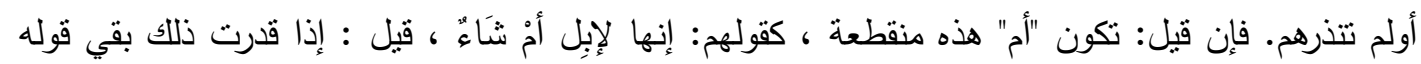

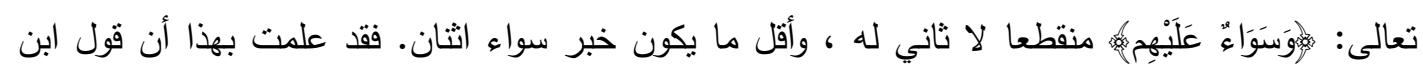

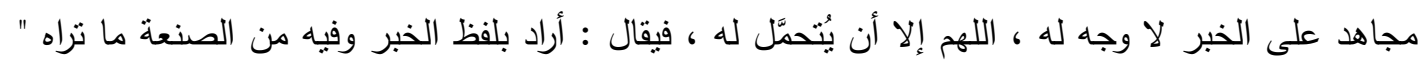

ومن حذف همزة الاستفهام أيضا قراءة رواها معاذ عن أبي عمرو وابن مجاهد عن أبي جعفر في

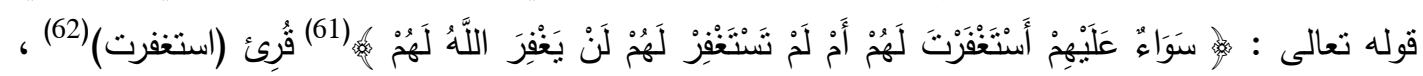

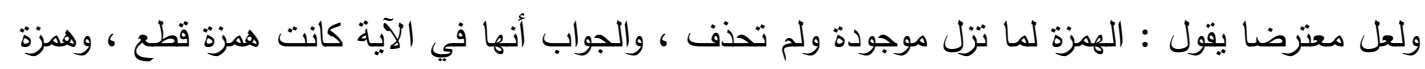

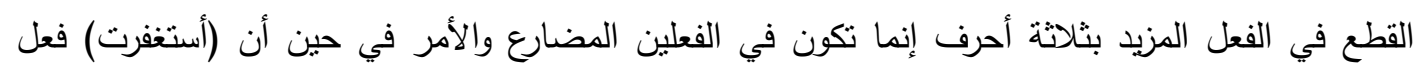

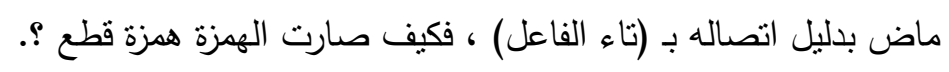

والجواب على ذلك أن ثمة همزة وصل كانت موجودة وحذفت بسبب دخول همزة الاستفهام عليها

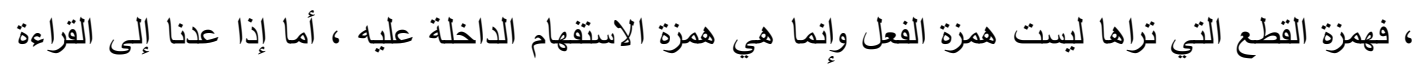

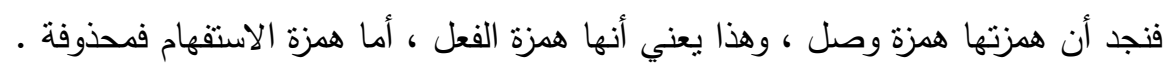




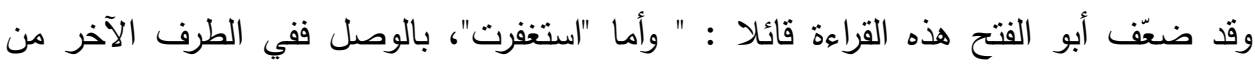

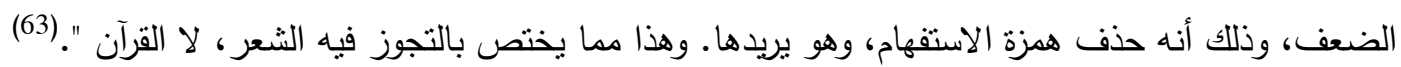

ومن الغريب حقا أن تحذف الهمزة وتزاد في قراءة واحدة وهي قراءة الزهري ونافع والحلواني قوله

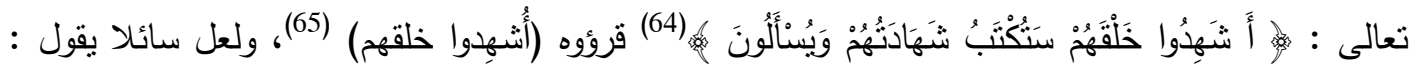

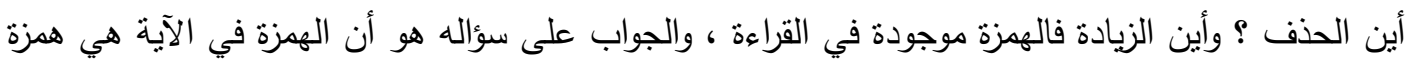

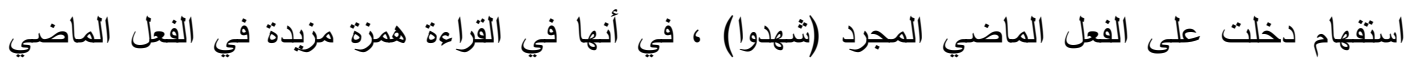

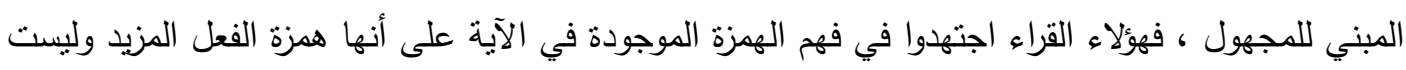

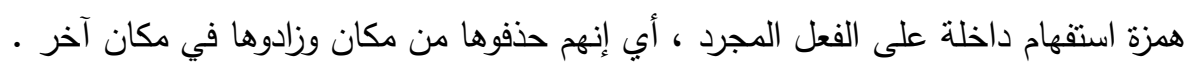

\section{ب . حذف همزة الاسم :}

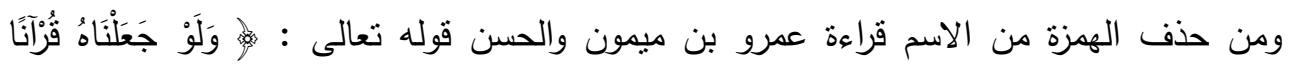

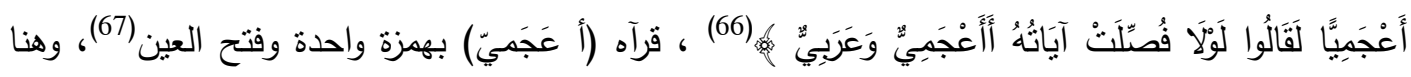

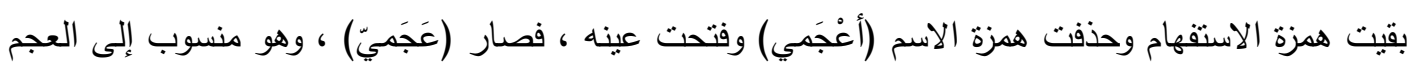

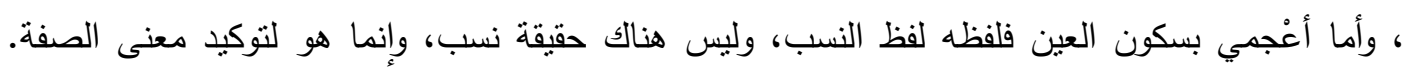
ونظيره قولهم : رجل أحمر وأحمري ، وأثقر وأثقري.

\section{2__حف الهمزة من آخر الكلمة :}

وأمثلته كثيرة أيضا ، ولم تكن هذه الأمتلة على وتيرة واحدة ، فمنها ما كان شاذا ، ومنها ما كان أنمان

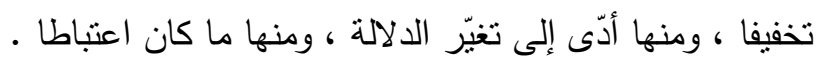

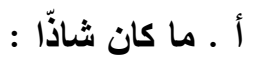

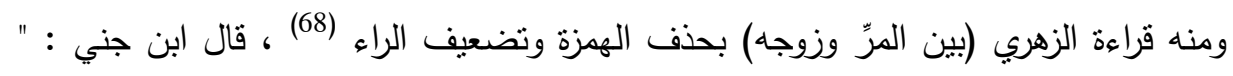

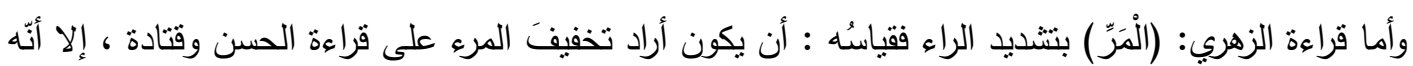


نوى الوقف بعد التخفيف ؛ فصار "الَْرَر" ثم ثقل للوقوف على قول من قال: هذا خالدّ ، وهو يجعلّ ، ومررت

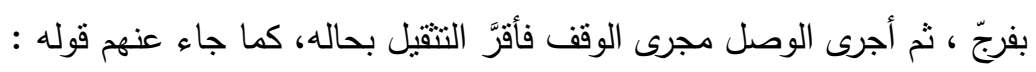

$$
\begin{aligned}
& \text { بِبازلٍ وجناء أو عَيْهٍَ ... كأن مهواها على الكَلْكَلِّ } \\
& \text { يريد: العيهل والكلكل، وكبيَتِ الكتاب: }
\end{aligned}
$$

ضخما يُحبٌُ الخُلقَ الأضخمَّا

فيمن فتح الهمزة ، يريد: الأضخم ، فثقّل ثم أطلق.

وفي هذا شذوذان؛ أحدهما: التثقيل في الوقف، والآخر : إجراء الوصل مجرى الوقف؛ لأنه من باب

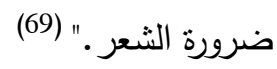

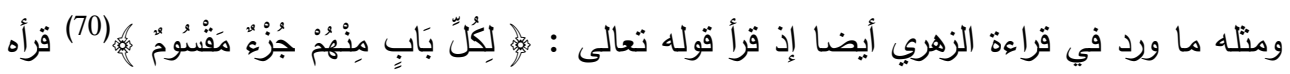

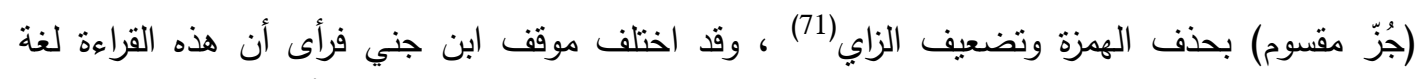

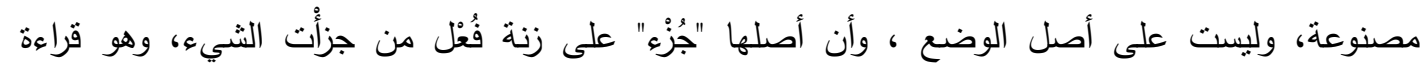

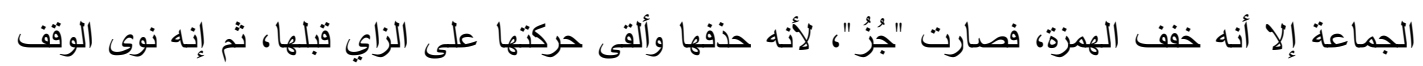

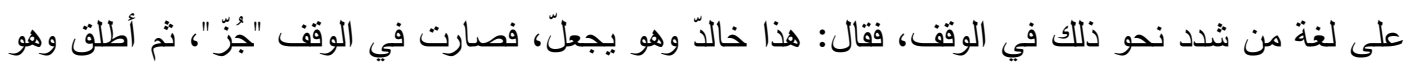

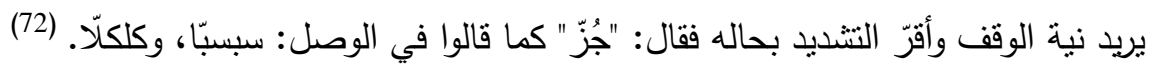

\section{ب ـ ما كان تخفيفا :}

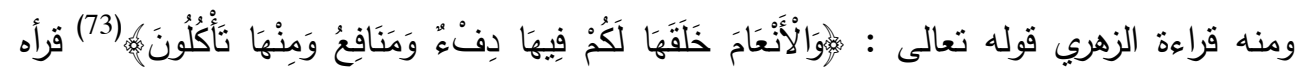
(دفُ) بغير همز (74) ، وقد وازن ابن جني بين هذه القراءة والقراءة السابقة (جزّ مقسوم) فرأى أن هذه القراءة

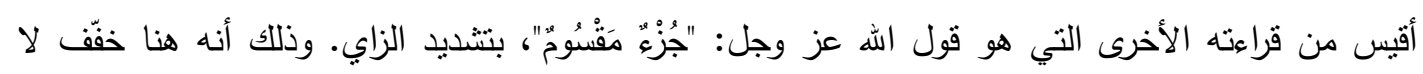

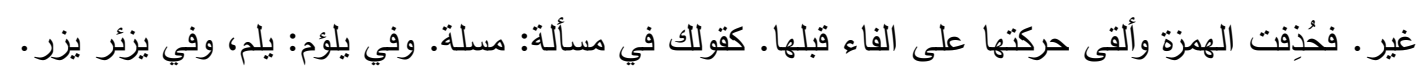

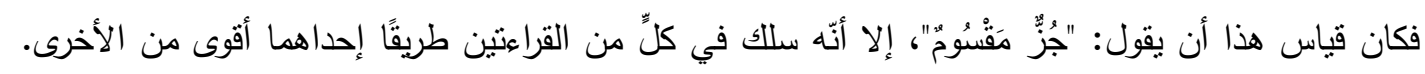




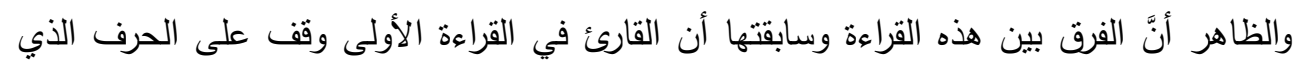

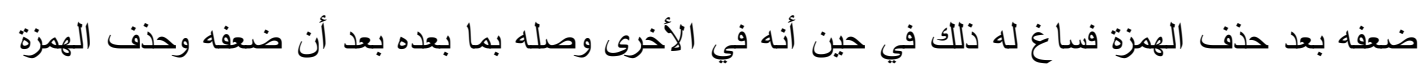

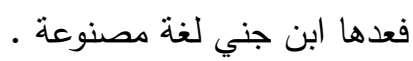

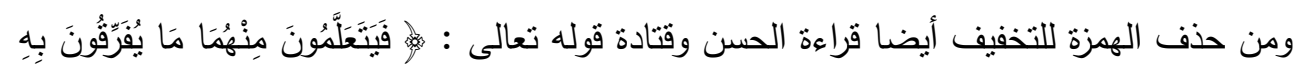

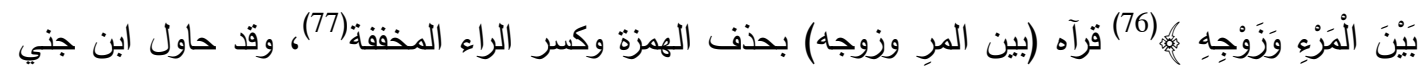

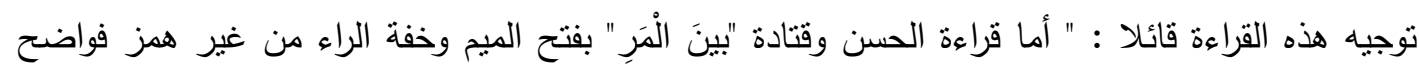

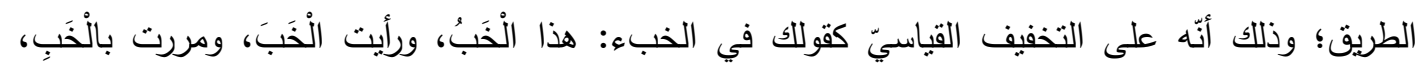

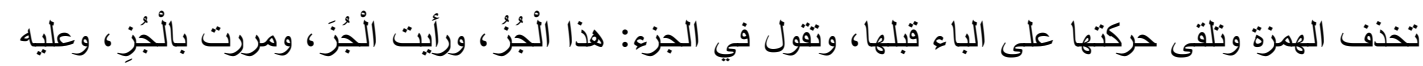

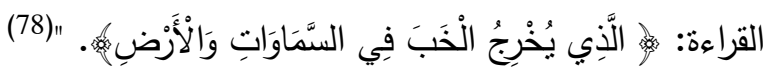

وإذا كان ابن محيصن قد امتاز بقلب همزة القطع وصلا في أغلب قراءاته فإن الزهري قد امتاز

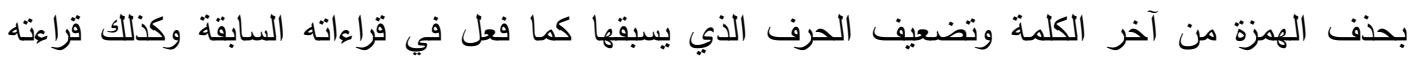

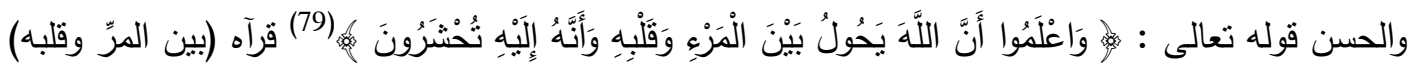

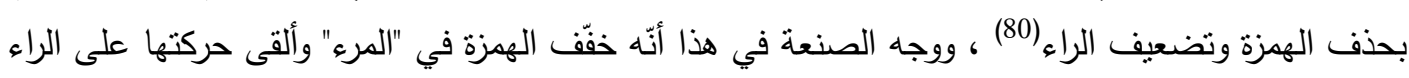

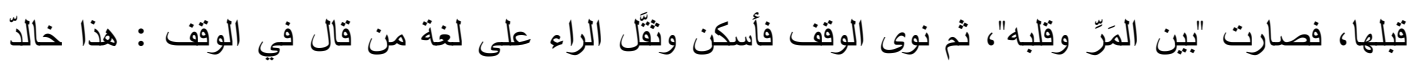

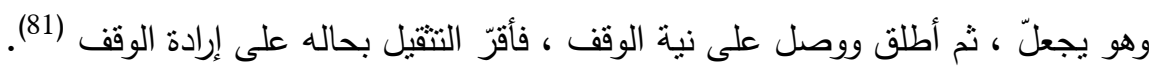

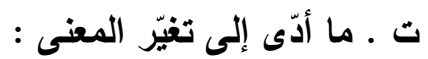

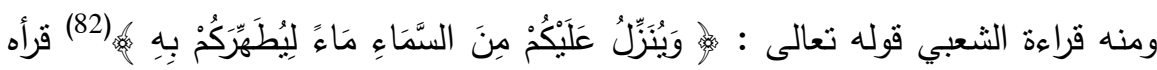

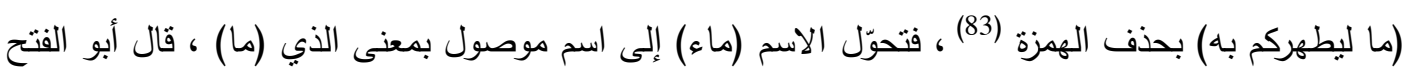

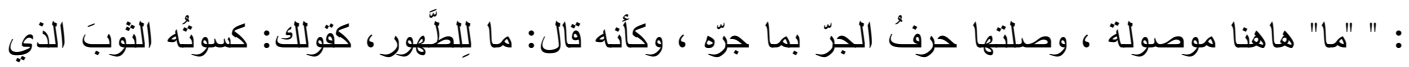
لافع البرد ، ودفعت إليه المال الذي للجهاد ، واشتريت الغلام الذي للقتال.

ألا ترى أنّ تقديره : ويُنَِّّل عليكم من السماء الماءَ الذي لأنْ يطهرّكم به ؛ أبي: الماء الذي لطهارتكم

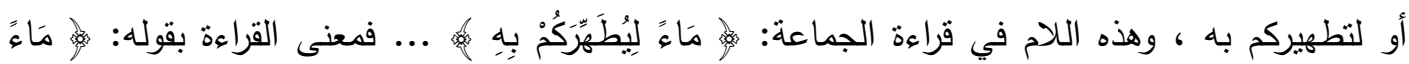




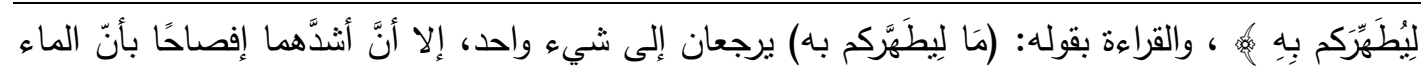

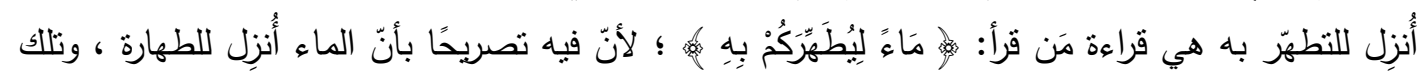

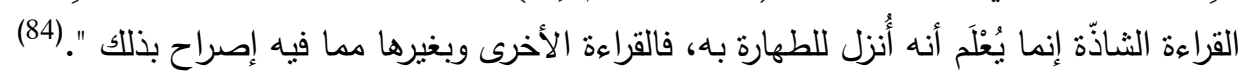

وهنا قد تغيّرت دلالة الكلمة من اسم الجنس (ماء) إلى الاسم الموصول المشترك (ما) ، فالمعنى

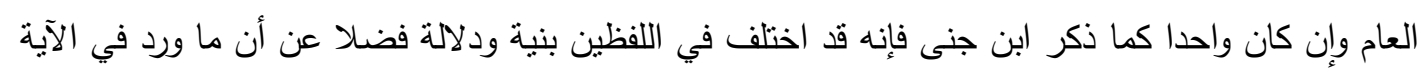

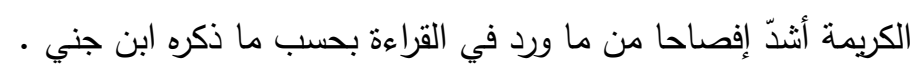

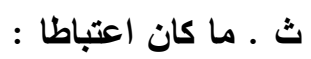

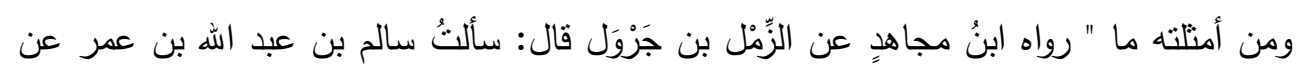

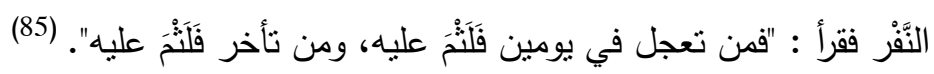

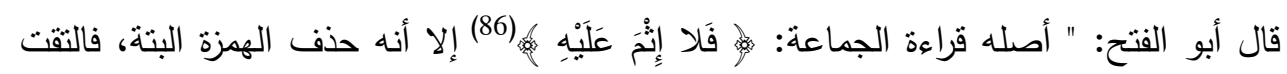
ألف "لا" وثاء "الاثم" ساكنين، فحذف الألف من اللفظ لالتقاء الساكنين، فصارت "قَلَنُْ عليه".

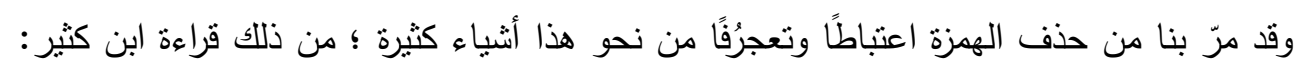

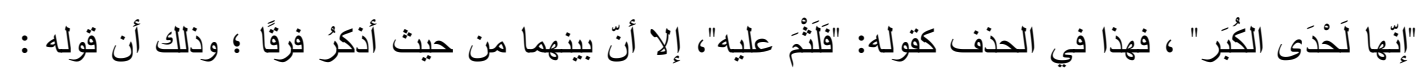

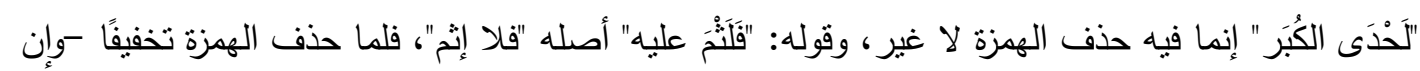

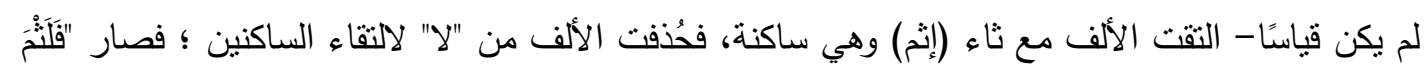

عليه"." (87)

وهذا الذي مر يعد من اللهجات التي تُحذف فيها الهمزة أو ثُبدل ، كما ضرح بذلك ابن جني في

كتابه الخصائص ، وهو من ما يحفظ ولا يقاس عليه ـ (88)

ومن النادر حقا أن تحذف هزتان في قراءة واحدة إحداهما من آخر الكلمة والأخرى من أولها تلك فأك

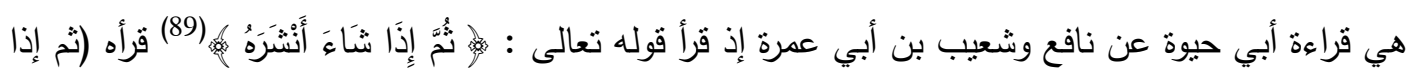
شا نشره) (90) فحذف الهمزة من آخر الفعل شاءواء والهمزة من أول الفعل (أنشره) !!!. 
لها كانت الهمزة بلا رمز يدل عليها ربما احتمل وجودَها القراءُ في عدد من كلمات القرآن فزادوها فيها في قراءاتهم ، وهذه الزيادة على نوعين : زيادة في أول الكلمة وزيادة في آخرها :

\section{1 _ـ_ زيادة الهمزة في أول الكلمة :}

أدّت زيادة الهمزة في أول الكلمة إلى تغيّر في الدلالة تارة ، وإلى تغيير بنية الفعل والدلالة العامة

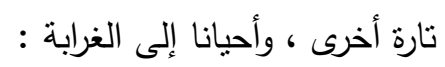

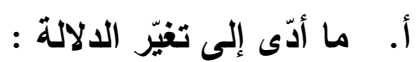

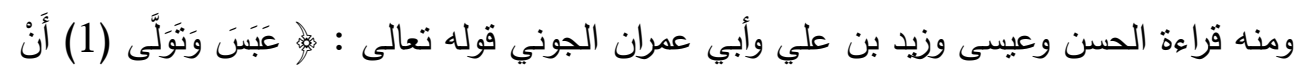

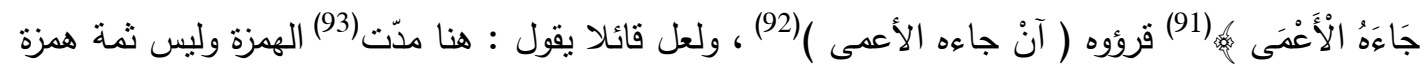

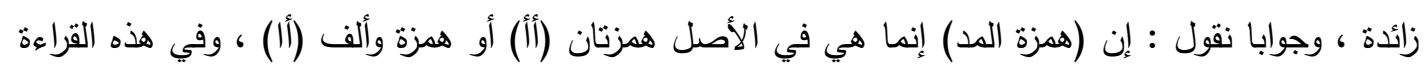

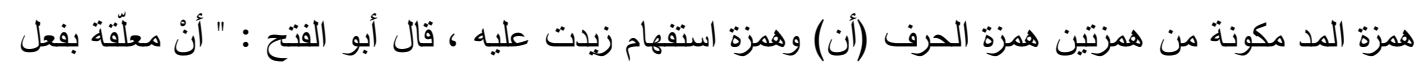

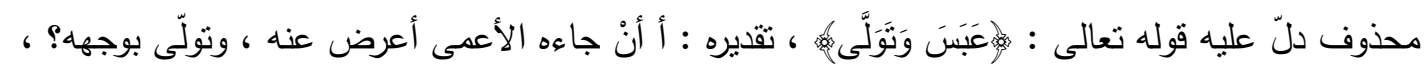

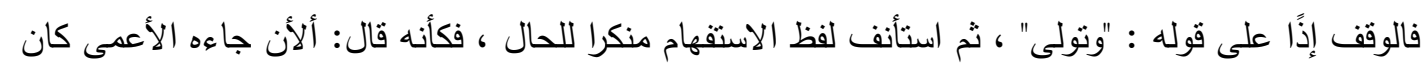
ذللك منه ؟ " (94).

ب ـ ما أدّى إلى تغيّر بنية الفعل :

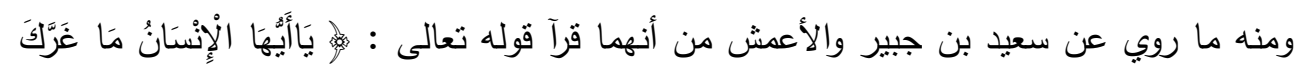

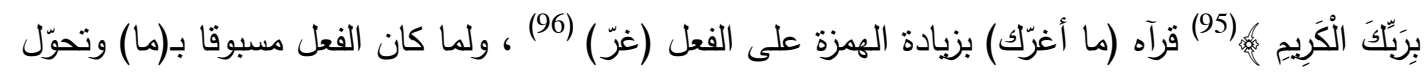

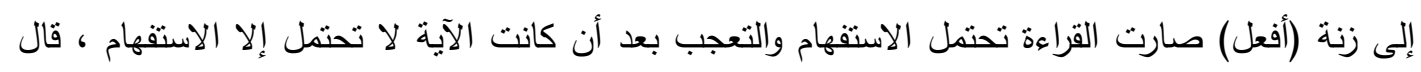

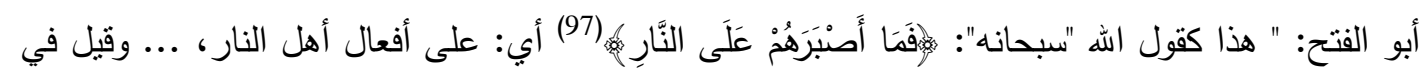

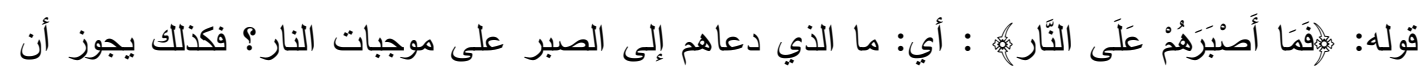




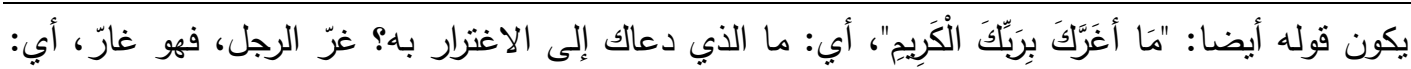
غفل ". (98)

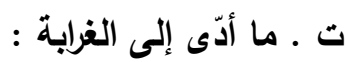

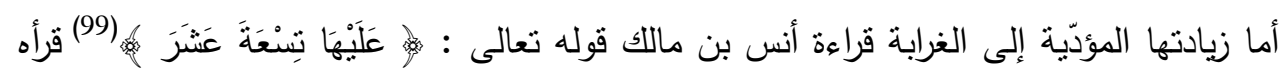

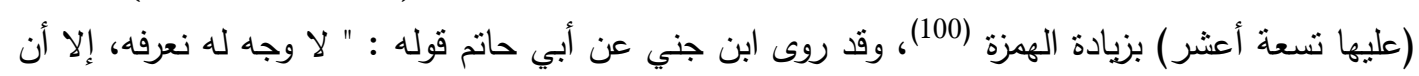

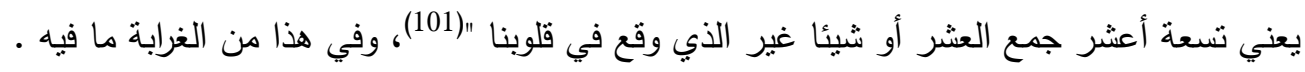

\section{2_زيادة الهمزة في آخر الكلمة :}

وقد أدّى إلى التغيير في بنية الاسم ودلالته تارة ، وإلى تغيير نوع الفعل ومعناه تارة أخرى ، وأحيانا أدّى إلى التمحل والتحريف في آي القرآن :

\section{أ ـ ما أدّى إلى تغيير بنية الاسم ودلالته :}

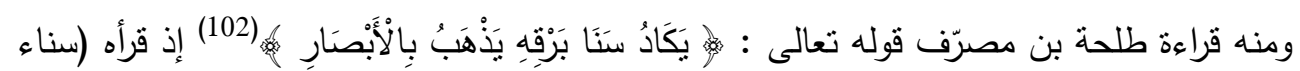

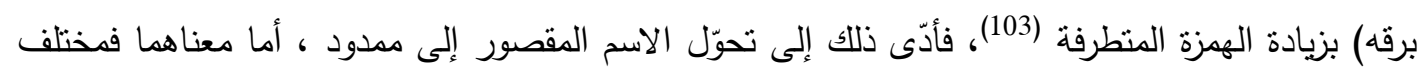

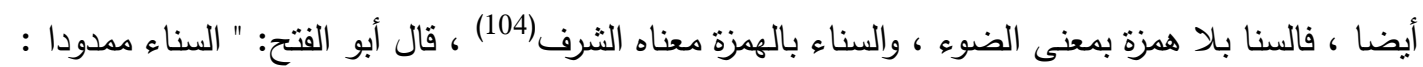

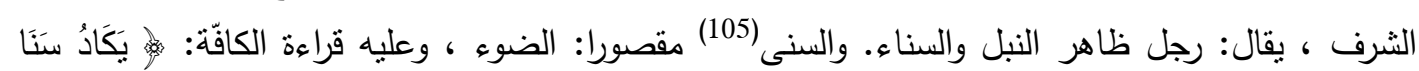

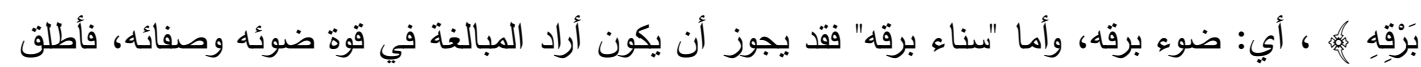
عليه لفظ الثرف، كقولك: هذا ضوء كريم ، أي: هو غاية في قوته وإنارته ، فلو كان إنسانا لكان كريما شريفًا (106) ."

ومن زيادة الهمزة في آخر الاسم وتغيّر البنية والدلالة أيضا قراءة ابن عباس وعكرمة والكلبي

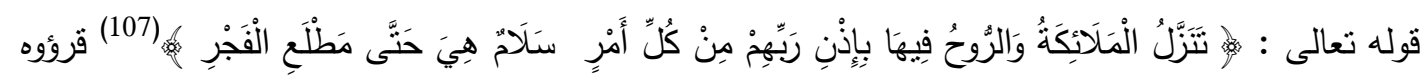

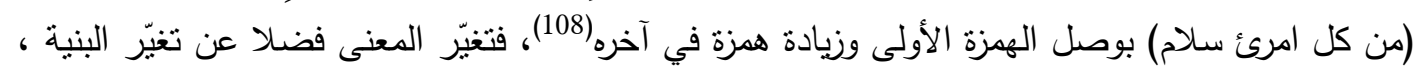

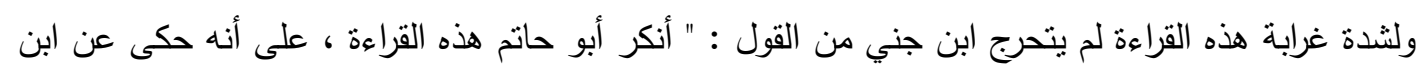




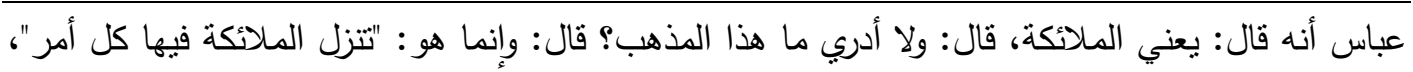

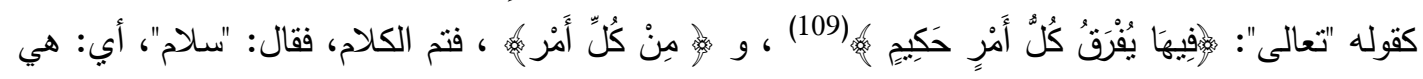

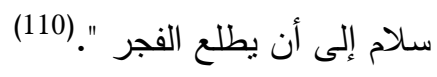

\section{ب ـ ما أدّى إلى تغيير نوع الفعل ودلالته :}

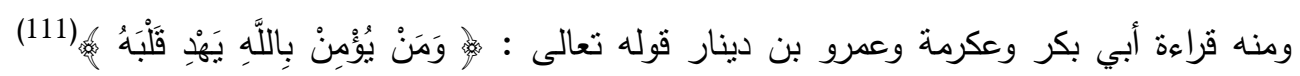

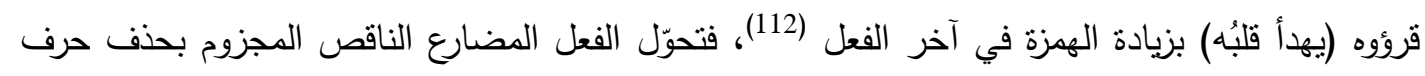

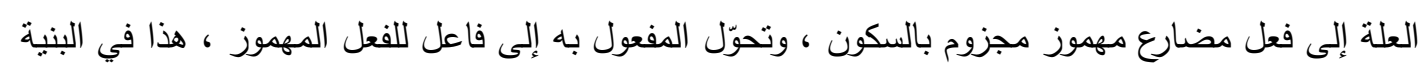

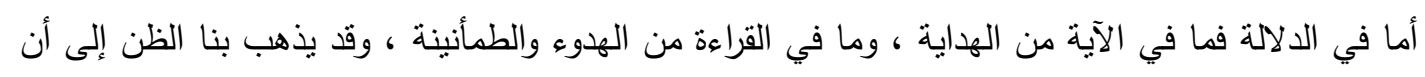

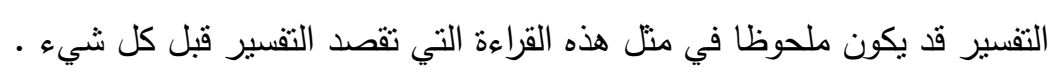
ت : ما أدّى إلى مخالفة النص القرآني :

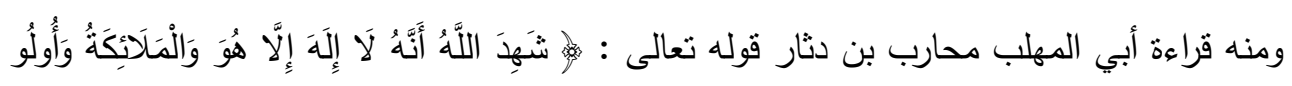

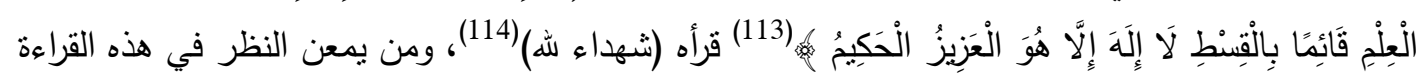

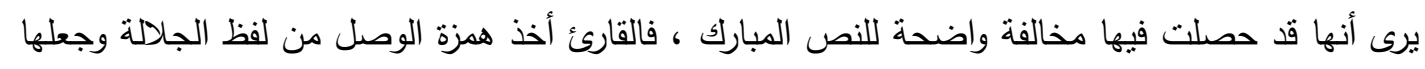

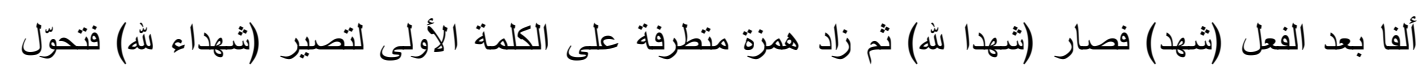

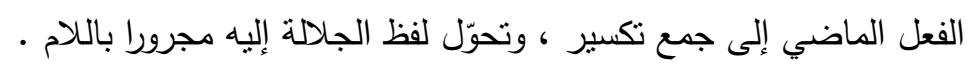

واللافت أن عددا من اللغوبين والمفسرين حين أوردوا هذه القراءة لم يعلقوا على ما حصل من تمحل

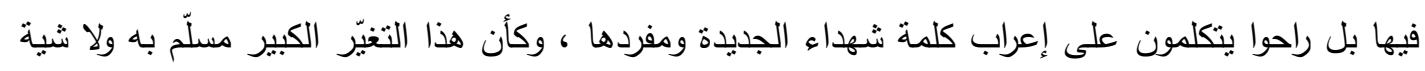

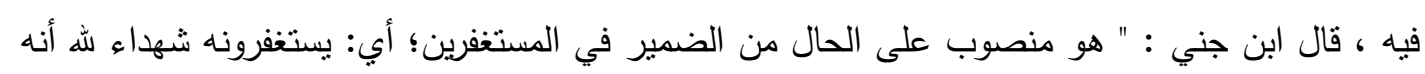
لا إله إلا هو ، وهو جمع شهيد، ويجوز أن يكون جمع شاهد؛ كعالم وعلماء، والأول أجود ، "(115) . 


\section{المبحث الثالث}

\section{قراعة الهمزة بين إثباع حركتها (القتحة) وقصرها}

أولا : إشباع حركة الهمزة :

كثثرا ما تأتي الههزة محرَّكة بالفتح في أوّل الكلمات (أَ) ، ولمّا كانت ثُرسَم ألفًا (ا) من دون علامة

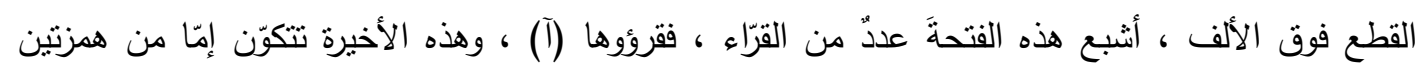

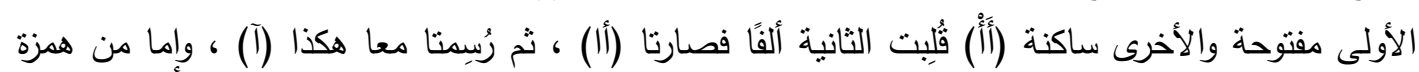

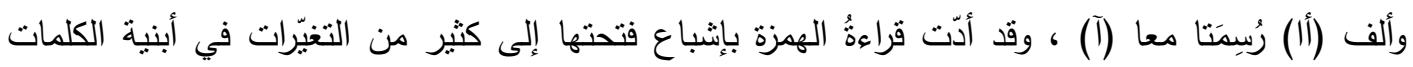

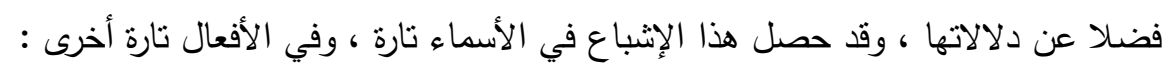

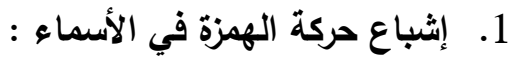

أدّى إثباع حركة الهمزة إلى تغيّر الاسم إلى مشتق الاءعة ، وتحول الاسم المفرد إلى جمعه ، وتحول الاسم إلى فعل ، وقد تغيّرت الدلالة فيها جميعا :

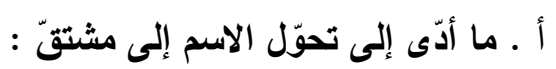

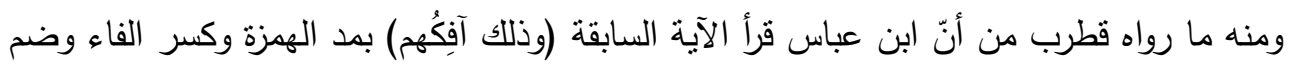

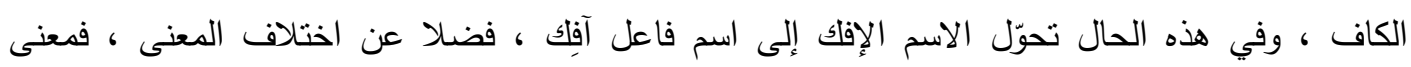

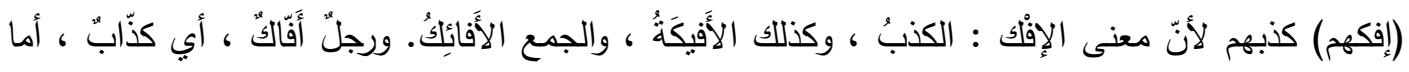

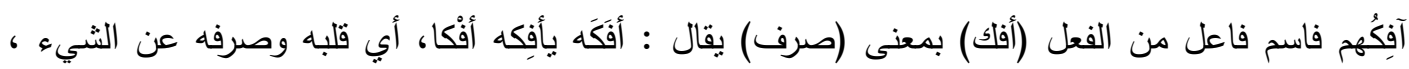

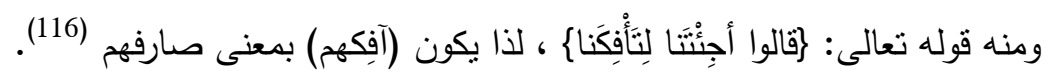

ب ما أدّى إلى تحوّل الاسم المفرد إلى جمعه :

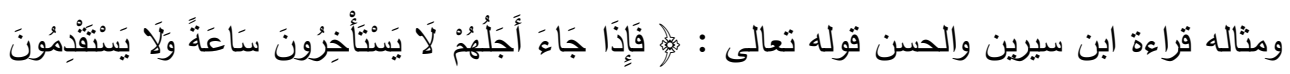

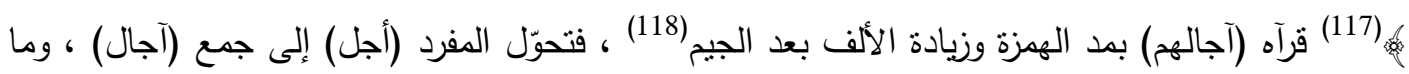

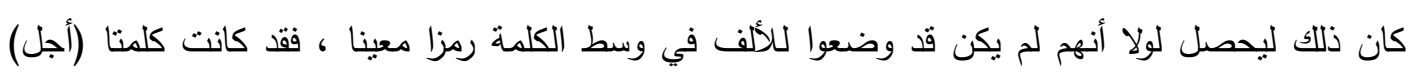


و (آجال) ترسمان هكذا (احل) من دون تعيين الهمزة أو نقط الحاء أو زيادة الألف ، أي تحتمل الحالتين

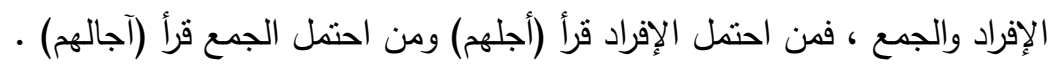

\section{ت ـ ما أدّى إلى تحوّل الاسم إلى فعل :}

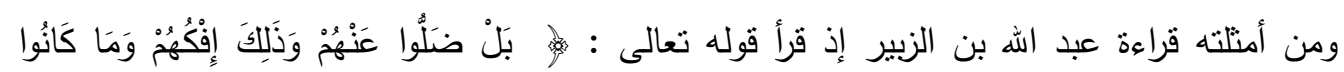

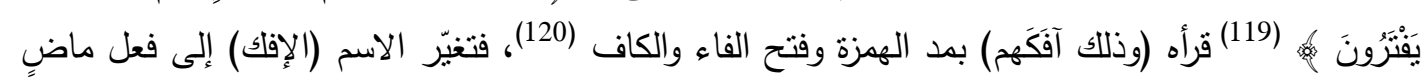

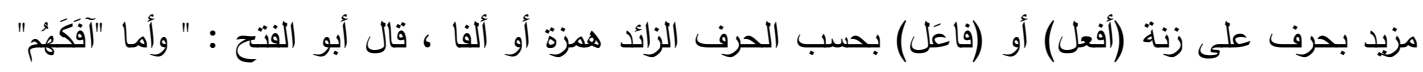

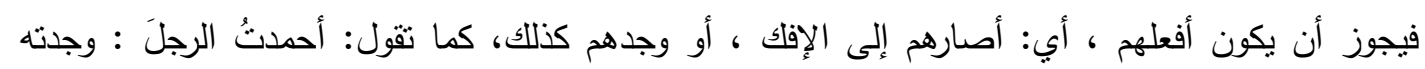

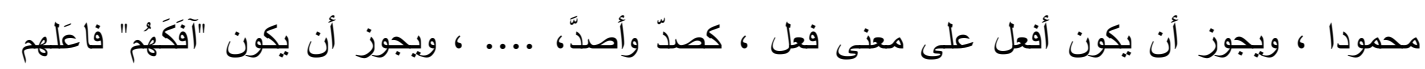

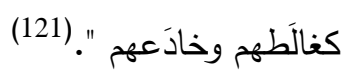

\section{2 ـ إشباع حركة الهمزة في الأفعال :}

وقد أدّى هذا إلى التغيّر في صيغة الفعل ، وتحول الفعل المجرد إلى مزيد ، ومنه ما أدّى إلى إلى

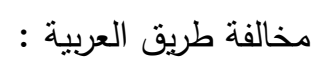

أ. ما أدّى إلى التغيّر في صيغة الفعل :

مثاله ما ورد في قراءة رواها ابن مجاهد عن أبي عمرو ومروية أيضا عن ابن محيصن والأعرج

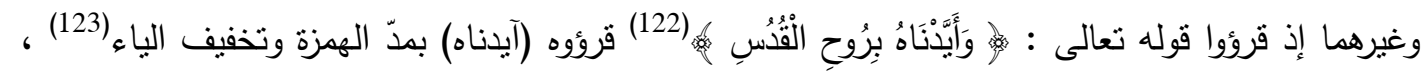

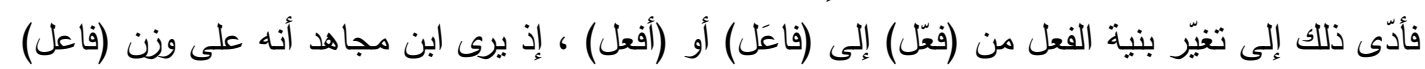

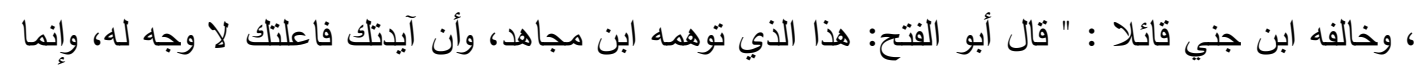
آيدتك أفعلتك من الأَّْد؛ وهو القوة " (124).

\section{ب ما أدّى إلى تحوّل الفعل المجرّد إلى مزيده :}

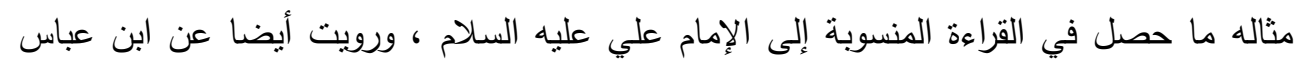

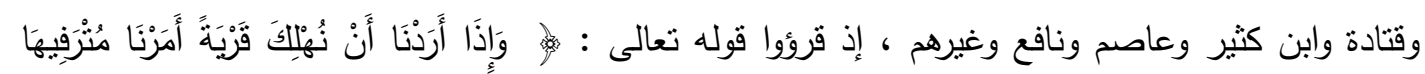




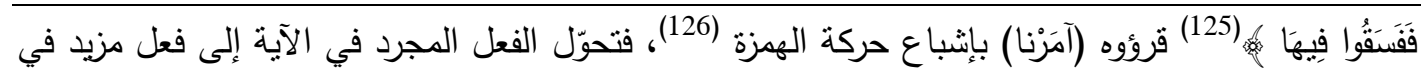

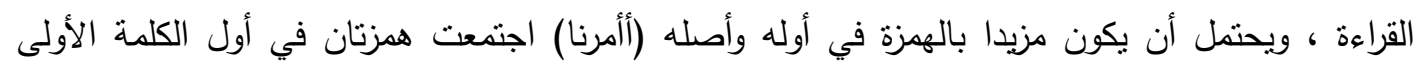

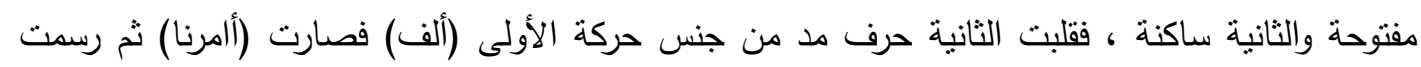
الهمزة والألف على شكل همزة مدية (آ) فصار (آمرنا) ، ويحتمل أيضا أن يكون مزيدا بالألف بعد فائه الأله وأصله (أمرنا) والأن

وقد يتحوّل الفعل من المجرد إلى المزيد ويبقى المعنى على حاله نحو ما ورد في قراءة الأعرج وأبي

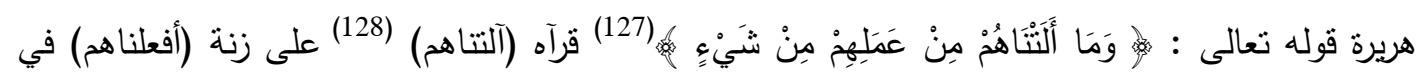

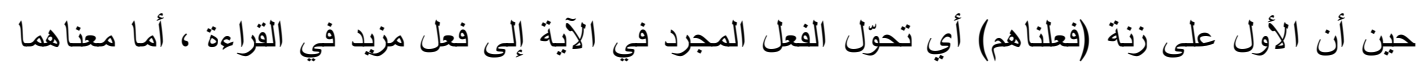

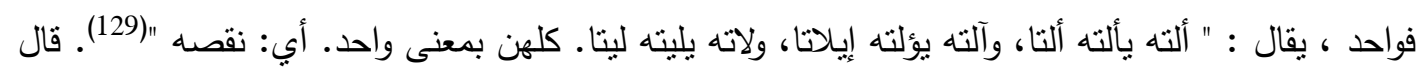

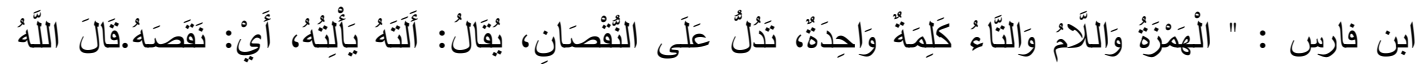

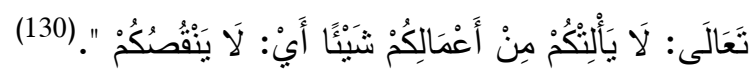

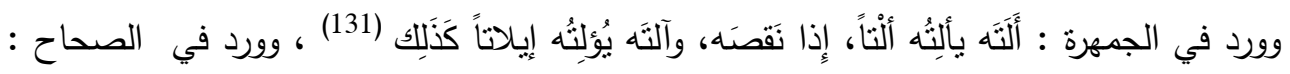

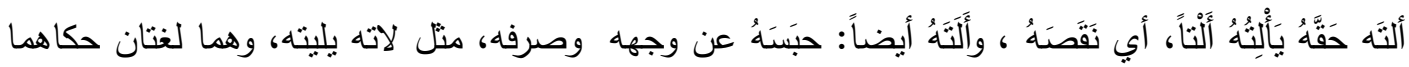
اليزيدي عن أبي عمرو بن العلاء. (132)

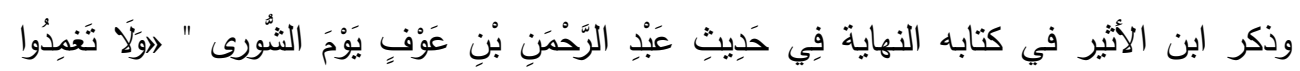

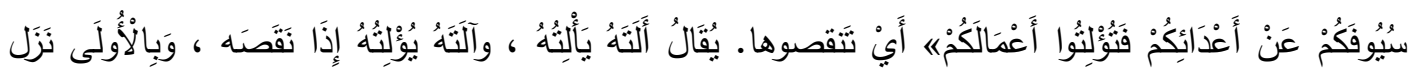

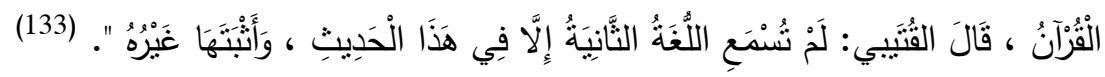

\section{ت ـ ما أدّى إلى مخالفة طريق العربية :}

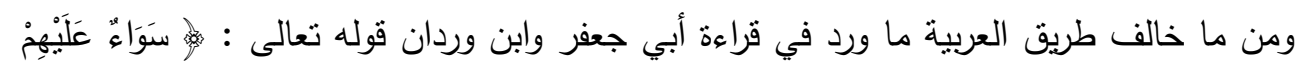

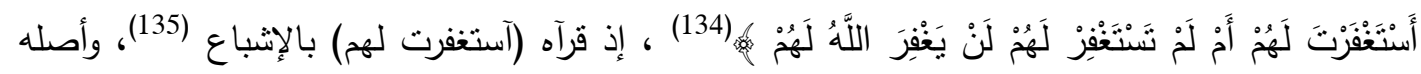

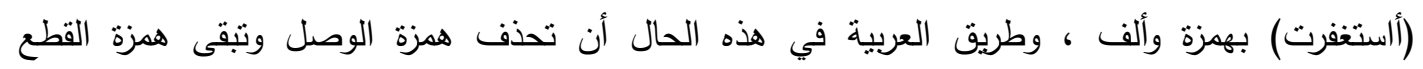

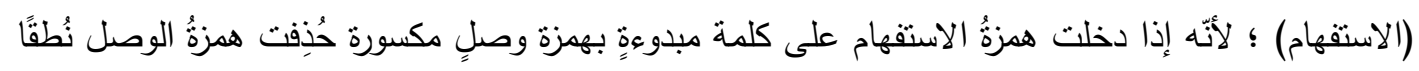




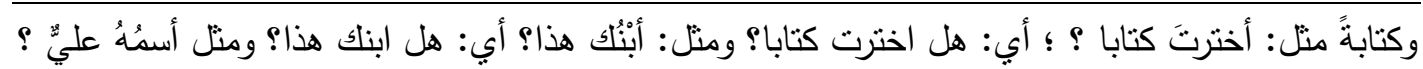

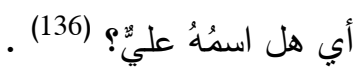

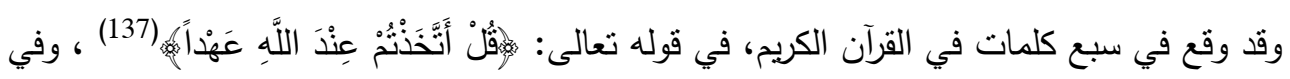

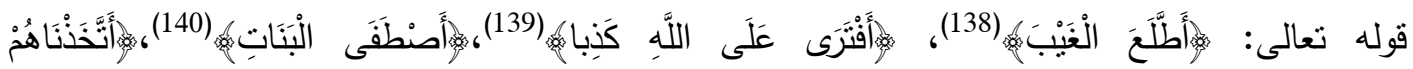
(143)

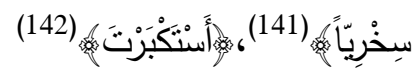

وأصل هذه الأفعال: أاتخذتم، ألطلع، ألفترى، أصطفى، أاتخذناهم، ألستكبرت، ألستغفرت، بهمزتين:

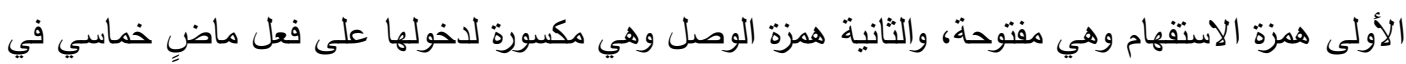

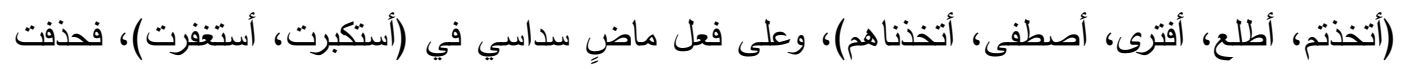
همزة الوصل استغناء عنها بهمزة الاستفهام.

ولا يتزتب على حذفها التباس الاستقهام بالخبر؛ لأن همزة الاستقهام تكون همزة قطع، وتكون مفتوحة أبدًا

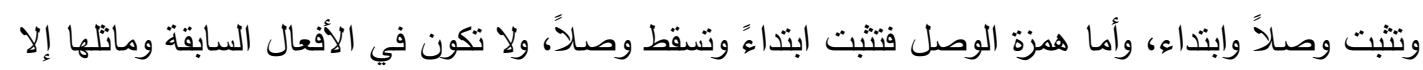
مكسورة .

إلا أن القارئ أبقى همزة الوصل مع همزة الاستقهام (القطع) فرسمتا معا هكذا (آ) ، وهذا إنما

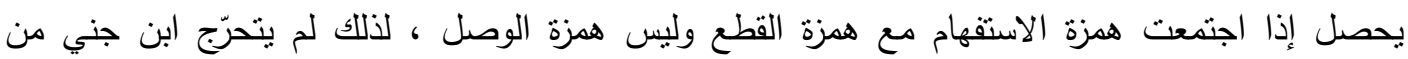

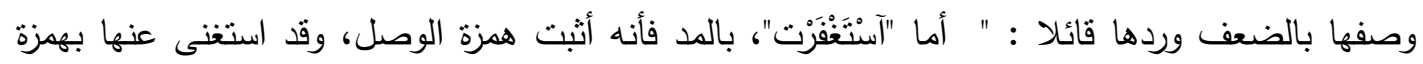

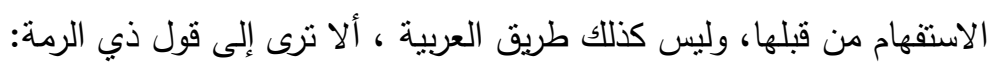
أستحدث الركب عن أشياعهم خبرا ... أم عاود القلب من أطرابه طرب " (144). وذكر العكبري (616هـ) قراءة أخرى هي ( آصنطفَى ) في قوله تعالى ": أصنطفَى الْبَنَاتِ" بالمد أيضا، وأثنار إلى أنها بعيدة(145) .

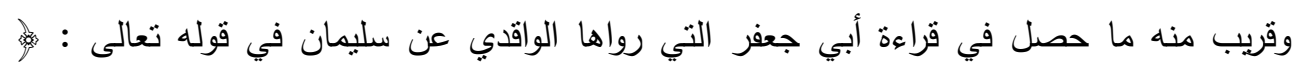

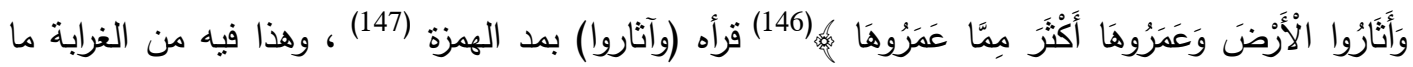
جعل ابن مجاهد يقول فيه : ليس هذا بشيء (148) . 


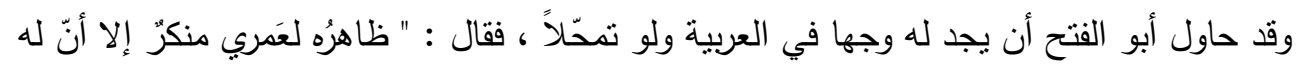

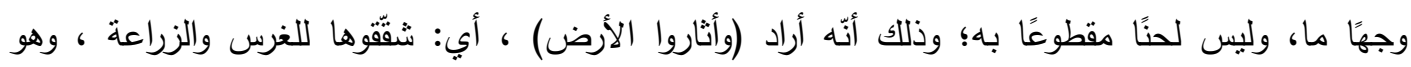

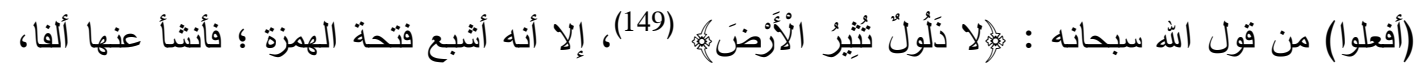
فصارت "آثاروا" وقد ذكرنا ذلك وشواهده في نحو قول ابن هرمة:

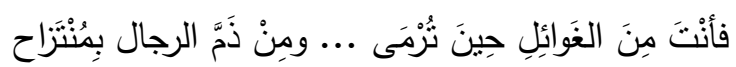
يريد: بمنتزح ، (منفعل) من النازح ، فأنشبع فتحة الزاي ، فأنشأ عنها ألفًا " (150) ، وهو يعلم أنّ هذا

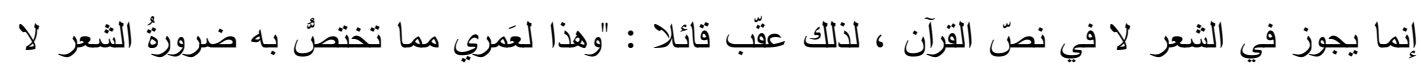
تَخَيُرُ القرآن" (151).

\section{ثنانيا : عدم إثباع حركة الهمزة :}

ذكرنا سابقا أنّ الهمزة (آ) تتكوّن إما من همزتين الأولى مفتوحة والأخرى ساكنة (أَآْ) قُلبت الثانية

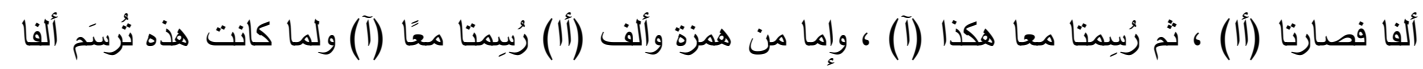

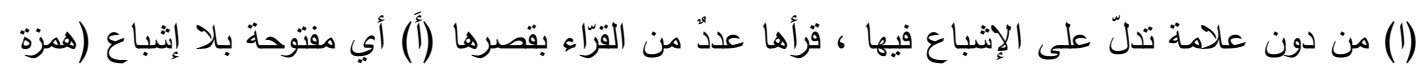

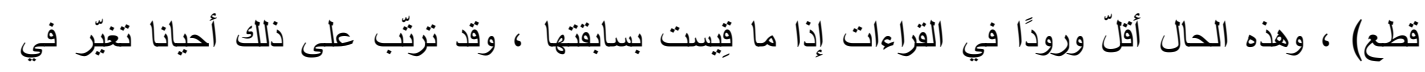
الدلالة فضلا عن تغيّر البنية.

وقد حصل عدم إثباع حركة الهمزة في الاسم فأدّى إلى تحوّله إلى مفرد بعد أن كان جمعا ، وحصل في الفعل فتغيّرت صيغة الفعل من المزيد إلى المجرد :

\section{أ. ما أدّى إلى تحوّل جمع الاسم إلى مفرده :}

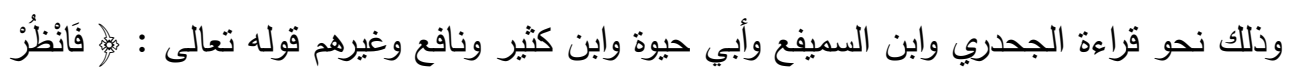

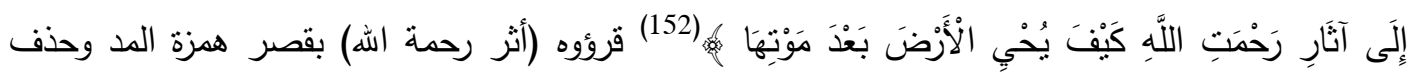

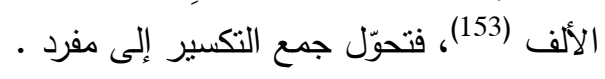


ولم تكن هذه القراءة لتحدث لولا أن الألف لم يكن لها رمز إذا جاءت في وسط الكلمة ، فكلتا

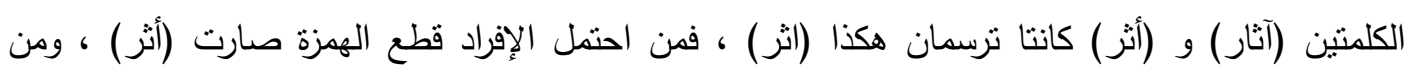

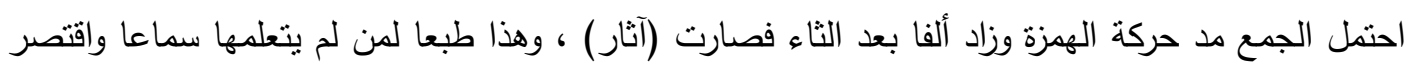

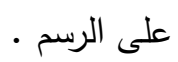

\section{ب ما أدّى إلى تحوّل الفعل المزيد إلى مجرّده :}

وكذلك حصل قصر الهمزة في الفعل فتغيّرت صيغته من المزيد إلى المجرد ومن أمتلته قراءة

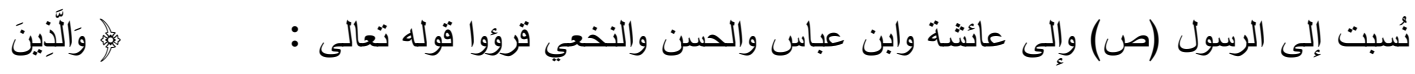

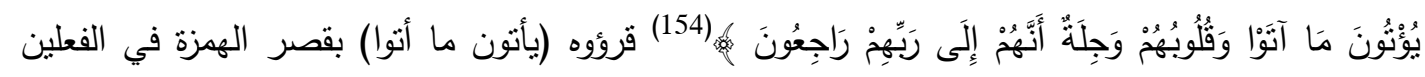

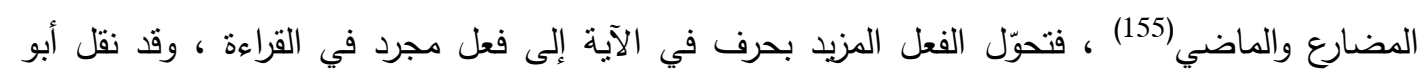

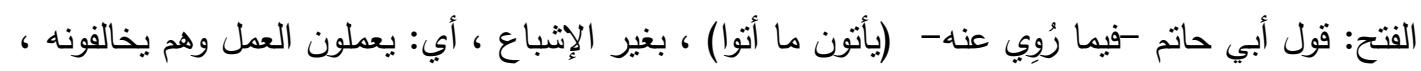

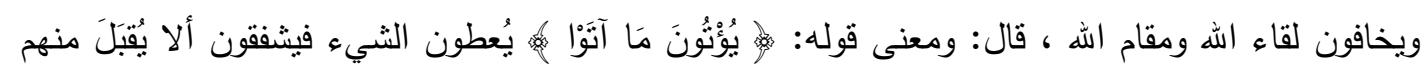

ثم ذكر أنه حُكي عن إسماعيل بن خلف أنّه قال: دخلتُ مع عبيد الله بن عمير الليثيّ على عائشةَ، آلَّ.

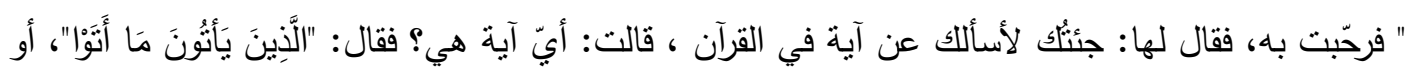

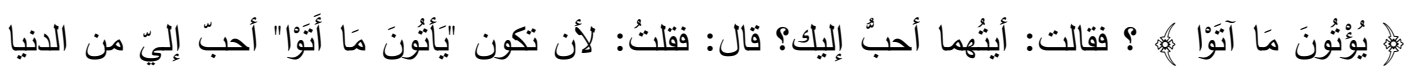

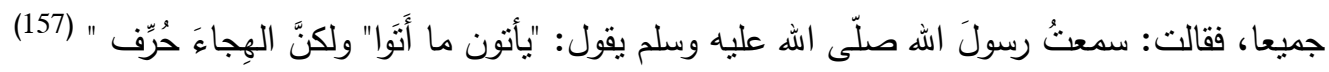

وهذه الرواية ، لو صحّت ، كفيلةُ بتأييد ما يذهب إليه الباحثان وقبلهما كثثر من الباحثين من أن

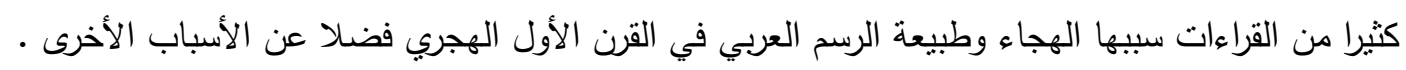




\section{المبحث الرابع}

\section{قراعة الهمزة بين القتح والكسر والضمّ}

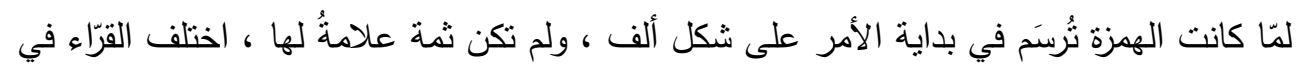

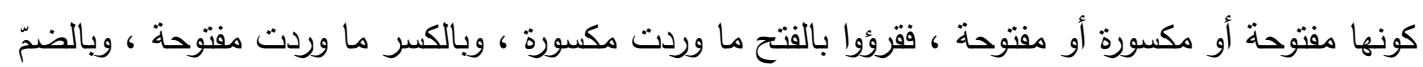

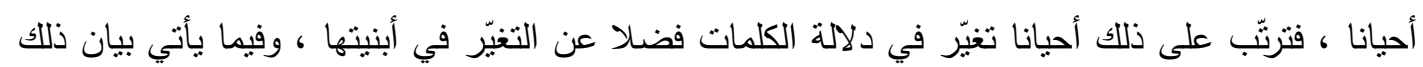

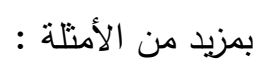

\section{أولا : فتح الهمزة المكسورة :}

لم تكن القراءة بفتح الهمزة المكسورة على وتيرة واحدة بالنسبة إلى أثره في الكلمة ، فتارة يكون فتح

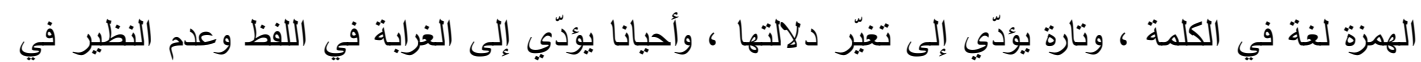

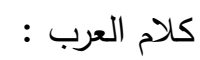

\section{أ ـ ما كان لغة فيها :}

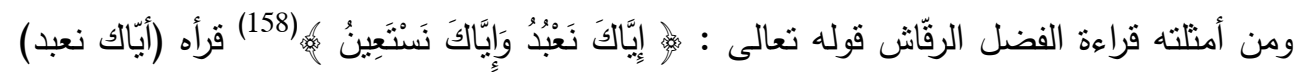

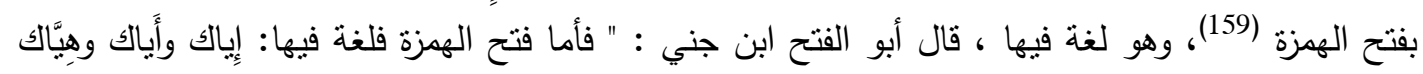

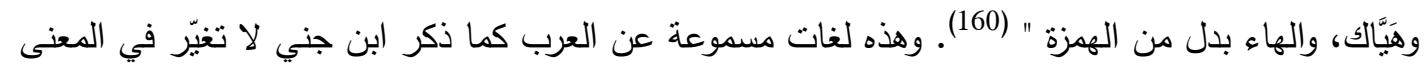
شيئا . وهئ

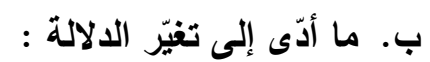

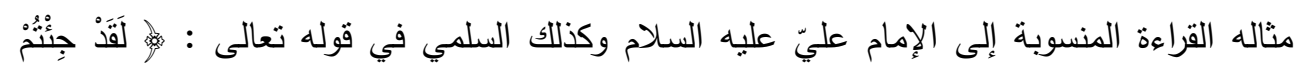

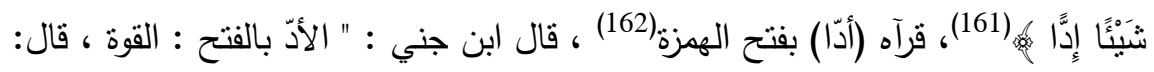

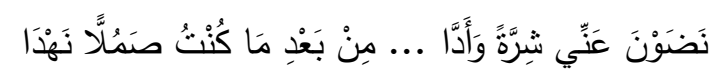




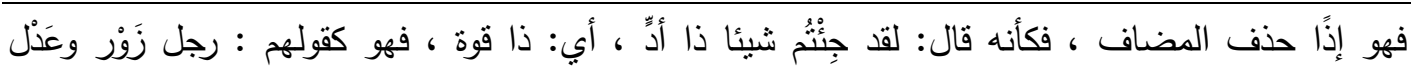

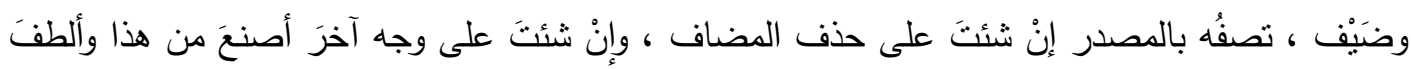

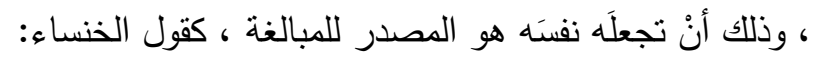

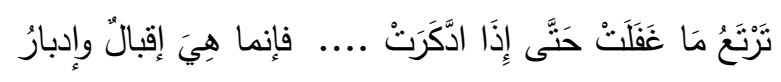

إنْ شئتَ على ذات إقبال وإدبار ، وإن شئتَ جعلتها نفسَها هي الإقبال والإدبار ، أي: مخلوقة منهما " (163)

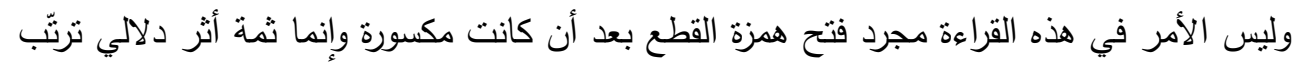

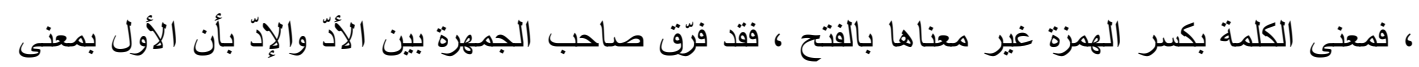

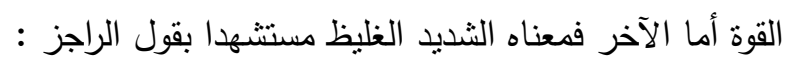

لمّا رأيتُ الأمرَ أمرا إدّا وَلمَ أَجْدْ من الفِرار بُدّا ملأتُ جِلدي وعظامي شَدَّا (164) وقال ابن فارس : الأدُ : القوة ، وهو الآد أيضاً والإدّد: الأمر العظيم. (165)، وذكر الجوهري أن الإدّ بالكسر

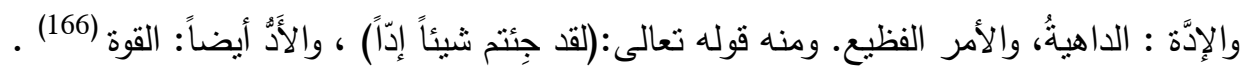

ت ـ ما أدّى إلى تغيّر بنية الأسماء :

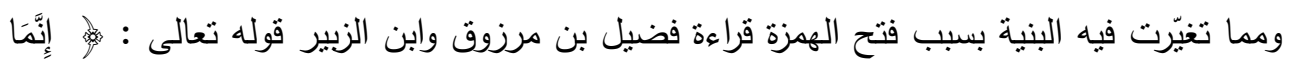

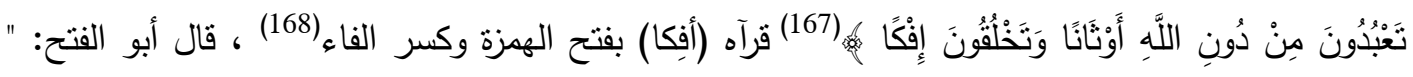

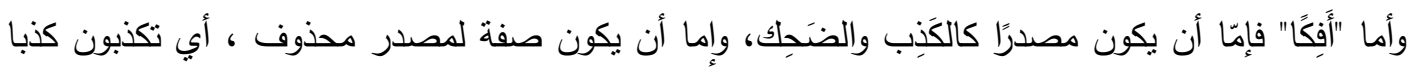

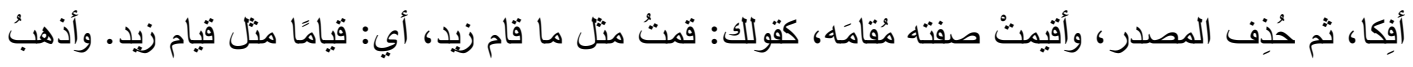

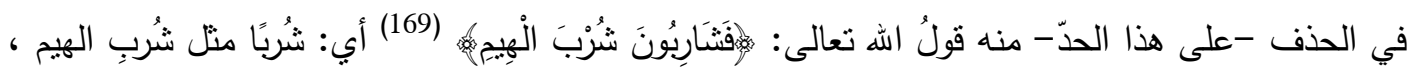

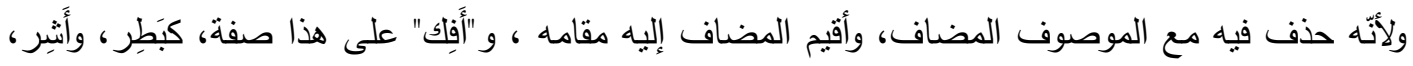




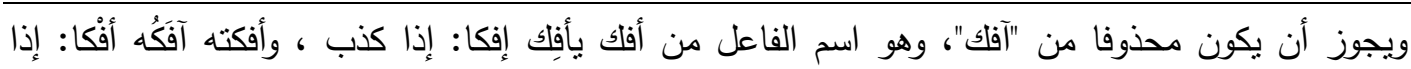

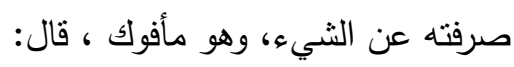
إنْ تَكُ عن أَحْسَنِ الْمُرُوءة مأ .... فُوُكًا فَفِي آخِرينَ قد أُفِكُوا

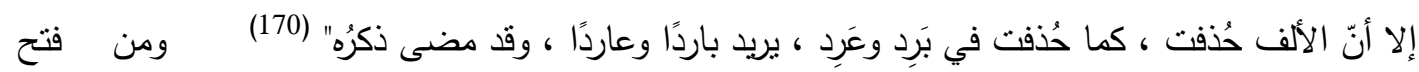

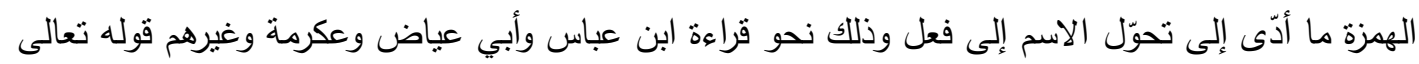

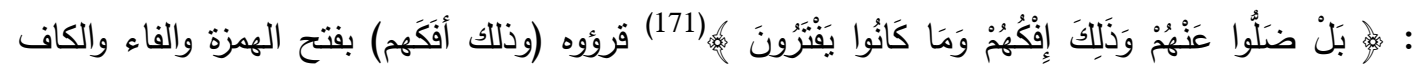

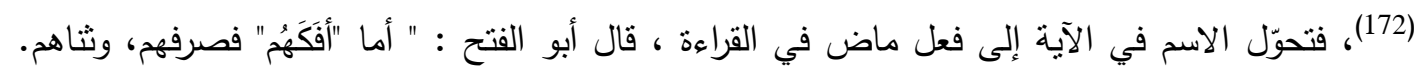
قال: - مقال

إن تلك عن أحسن المروءة ومأ ... فوكا ففي آخرين قد أفكوا

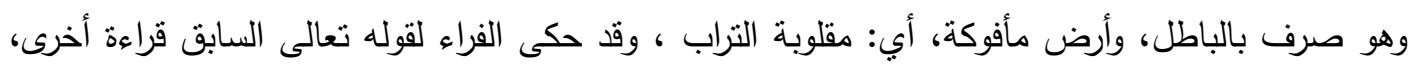

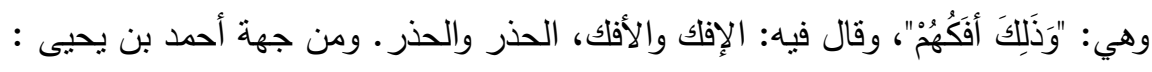

$$
\begin{aligned}
& \text { مالي أراك عاجزا أفيكا ... أكلت جديا وأكلت ديكا } \\
& \text { تعجز أن تأخذ ما أريكا } \\
& \text { الأفيك: المصروف عن وجهه وحيلته " (173) }
\end{aligned}
$$

ومنه ما أدّى إلى تحوّل المصدر إلى جمع وذلك نحو قراءة سالم بن أبي الجعد والأعمش والمطوّعي

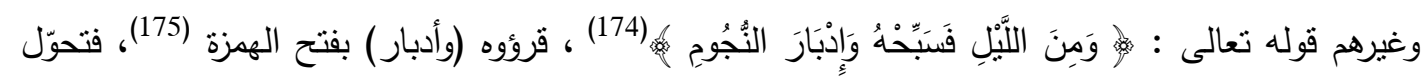

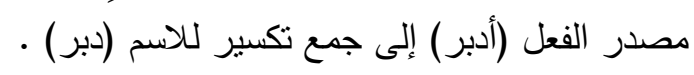


ومن فتح الهمزة مع تغيّر نوع الحرف ودلالته ما ورد في قراءة زيد بن أسلم وأبي جعفر القارئ قوله

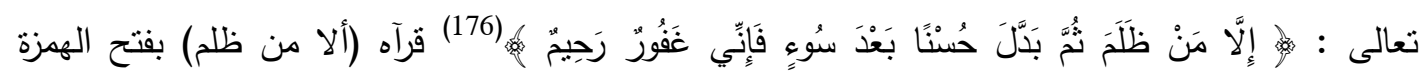

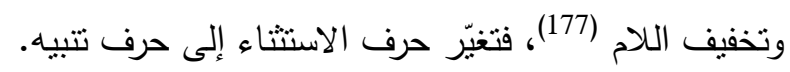

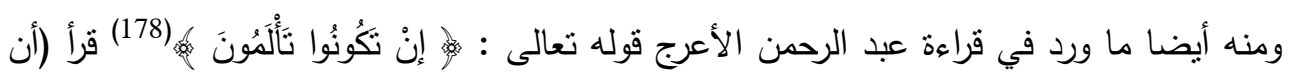

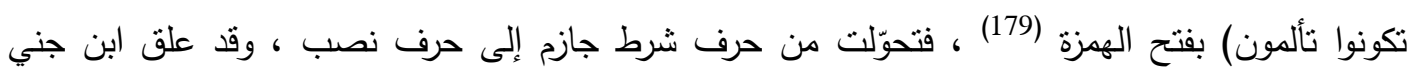

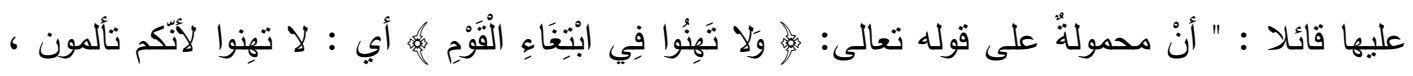

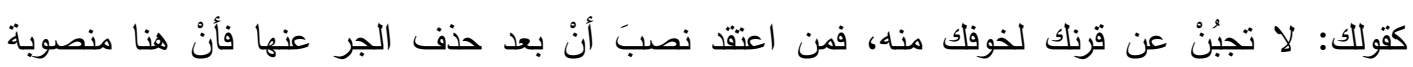

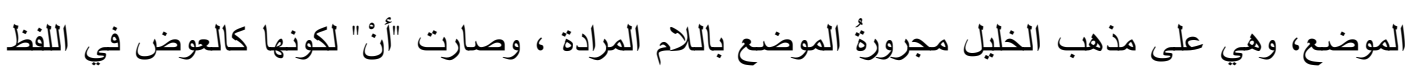
من اللام" (180).

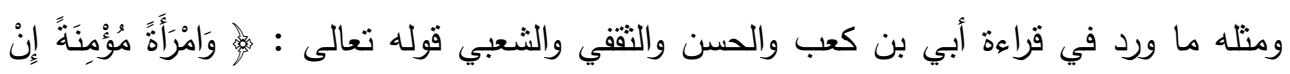

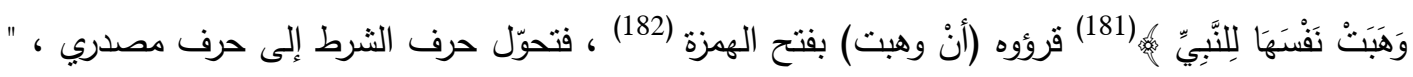

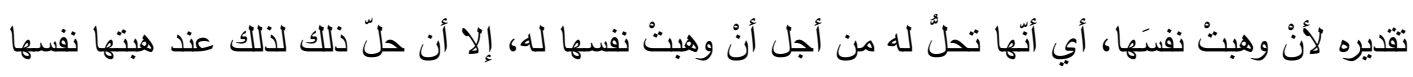
له وإن هي وهبت نفسها له.

وليس يعني بذللك امرأة بعينها قد كانت وهبت نفسها له، وإنما محصوله أنّها إنْ وهبت امرأة نفسها

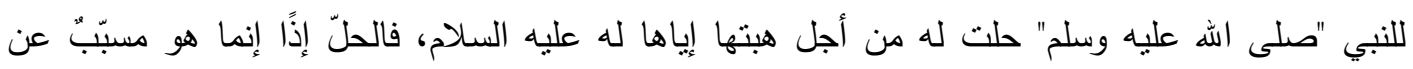

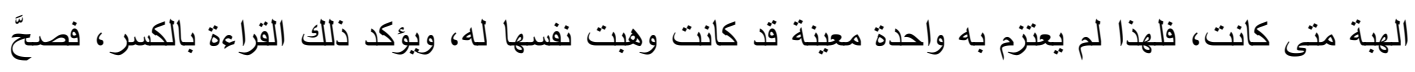
به الثرط" (183).

ومن فتح همزة (إنَّ) الحرف المشبّه بالفعل قراءة أبي جعفر والأعمش وسهل بن شعيب قوله تعالى :

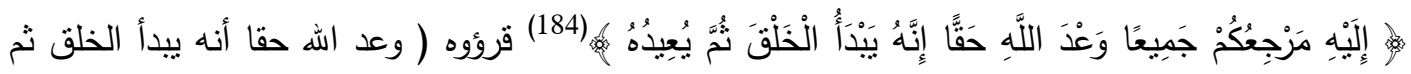

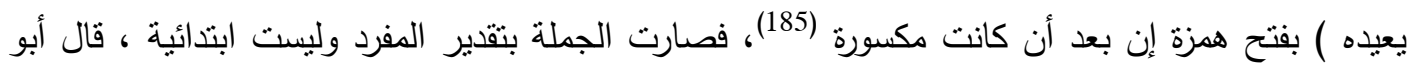

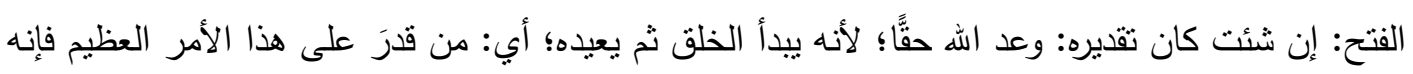


غني عن إخلاف الوعد، وإن شئت كان تقديره: أب وَعَدَ الله وعدًا حقًا أنه يبدأ الخلق ثم يعيده، فتكون "أنه"

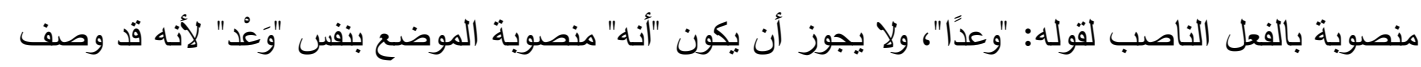

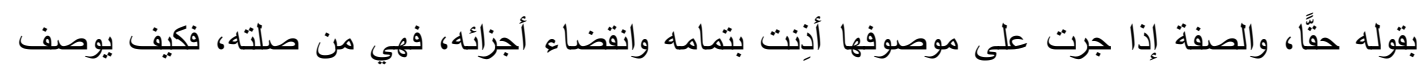
قبل تمامه؟ " (186).

\section{ج · ما أدّى إلى غرابة اللفظ}

ومن ما أدّى إلى الغرابة في اللفظ وعد النظير في كلام العرب قراءة الحسن قوله نعالى (والإنجيل)

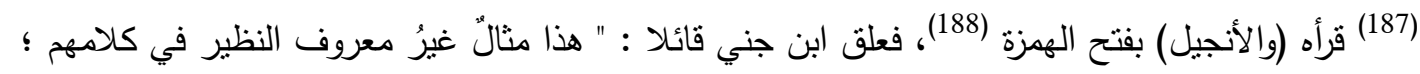

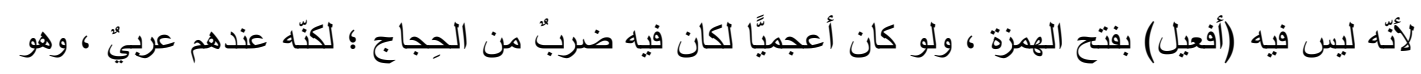

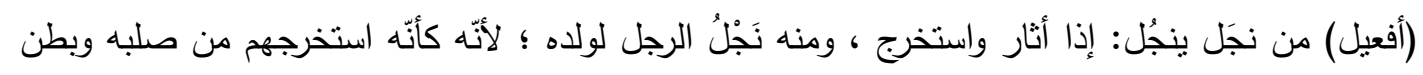
امرأته " (189).

ثنانيا : كسر الهمزة المفتوحة أو المضمومة :

لم يختلف كسر الهمزة عن فتحها في أنه أدّى إلى تتوّع في القراءات بين ما كان لغة في الكلمة ،

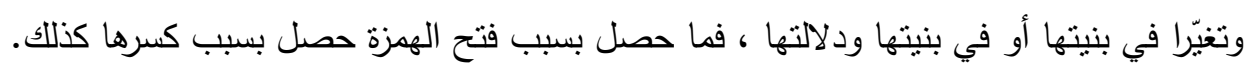

\section{أ. ما كان لغة :}

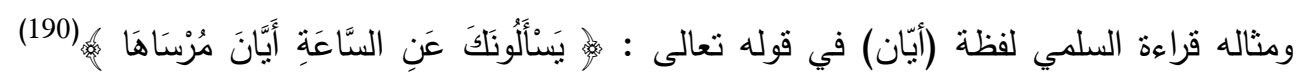

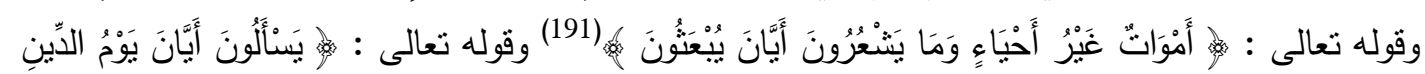

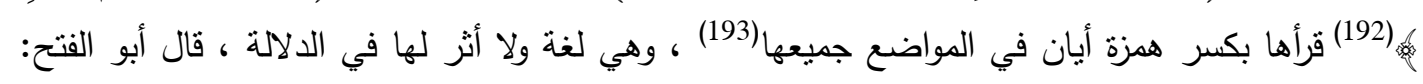

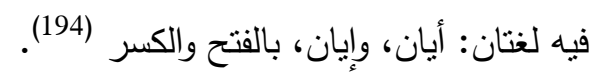




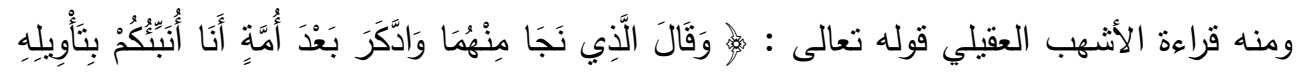

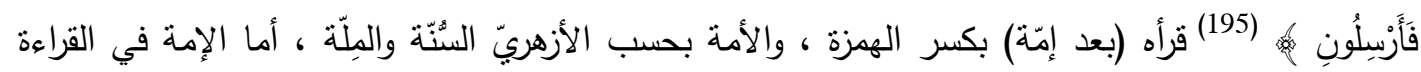

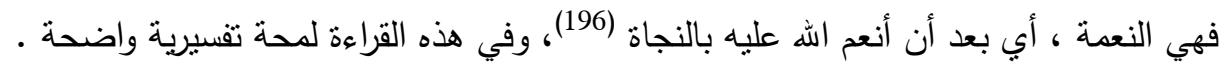

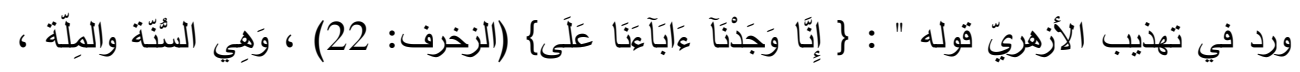

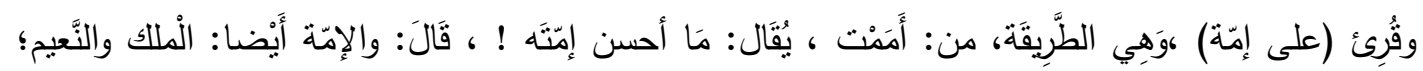

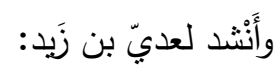

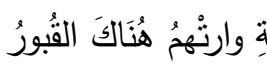

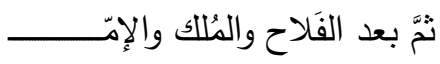
قََالَ: أَرَادَ: إِمَامَة المُللك ونعيمه .

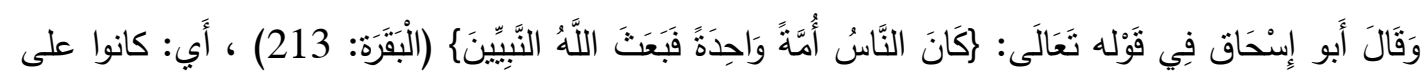
دينٍ وَاحِد.

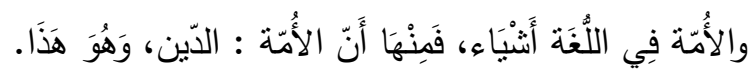

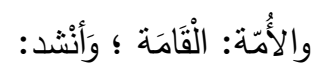
حِسان الؤجوه طِوال الأُمَنْ وَإِن مُعاوية الأَكْرمين أَي: طوال القَامات.

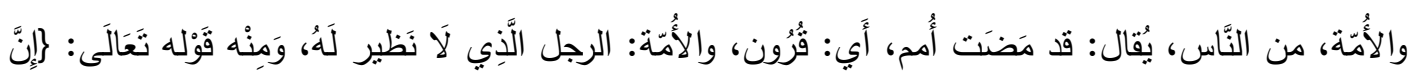

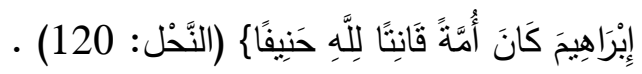
وَفَالَ أَبو عُبيدة: معنى قَوَله (كَانَ أُمة) أَي: كَانَ إمَاماً. والأمَّة: النِّعمة. 


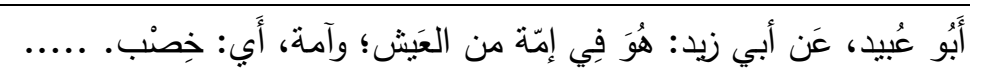

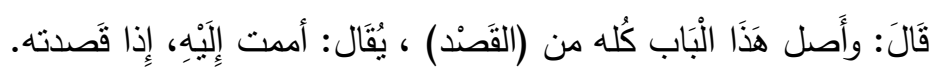

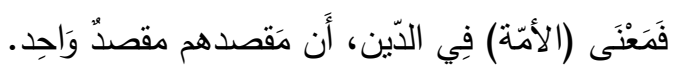

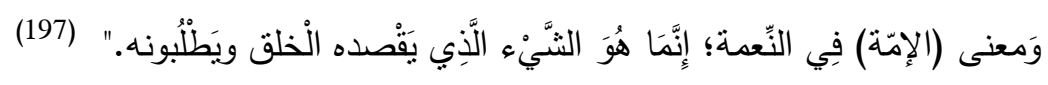

ومن يمعن النظر في أوّل قول الأزهريّ يرى أن ثمة قراءة بكسر همزة (أمة) فحوّلت دلالة الكلمة إلى الطريقة في حين أنها بمعنى الثريعة في الآية.

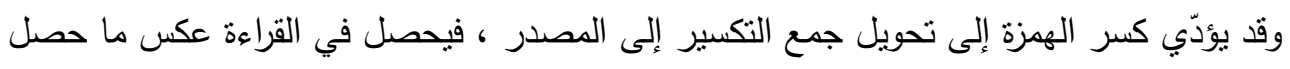

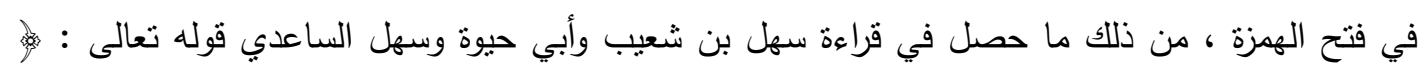

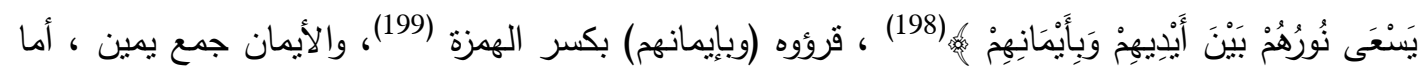

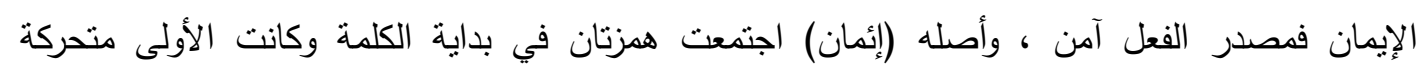

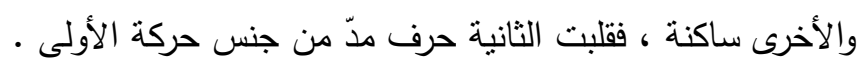

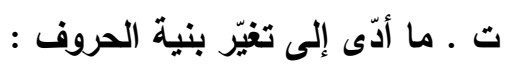

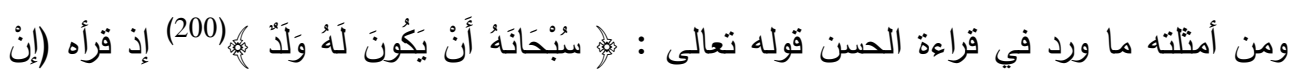

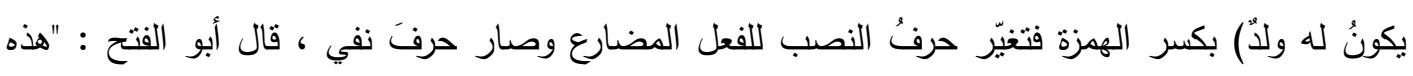

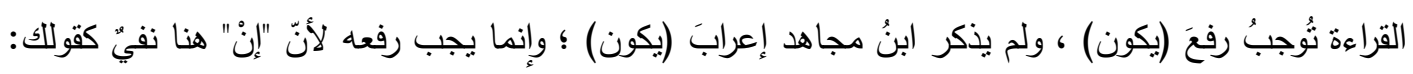

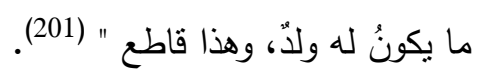

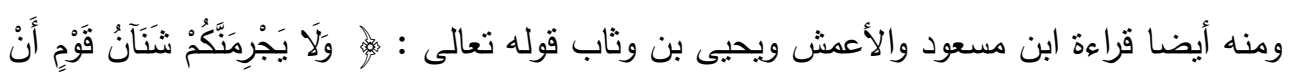

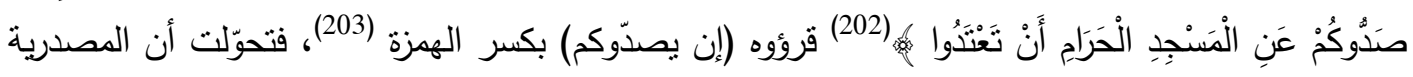

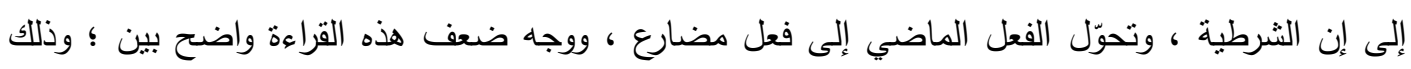

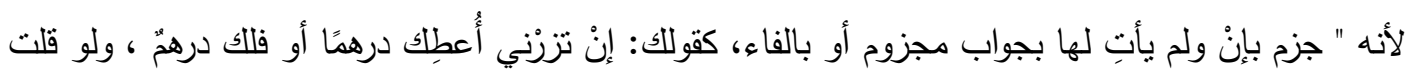

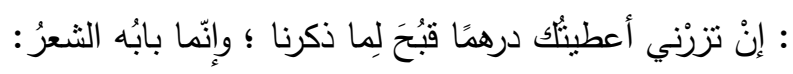




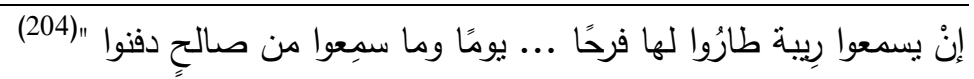

ثالثا : ضمّ الهمزة المفتوحة :

لم برد هذا الاستعمال في القراءات بكثرة كورود فتح الهمزة وكسرها ، ومن أمثلة وروده قراءة الأعرج

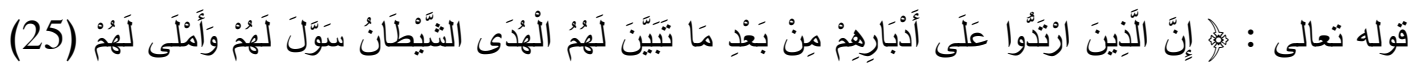

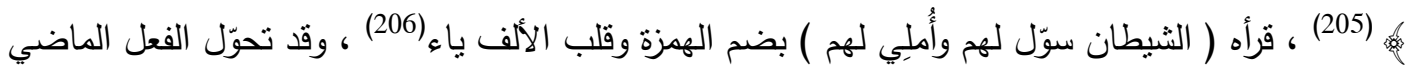

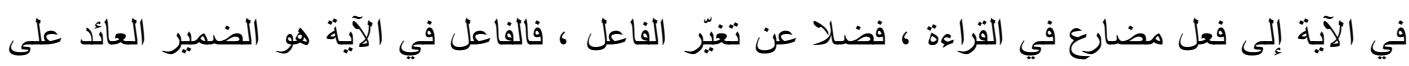

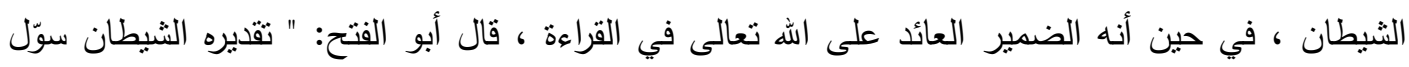

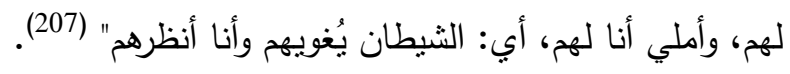

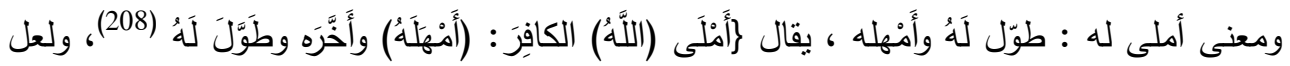

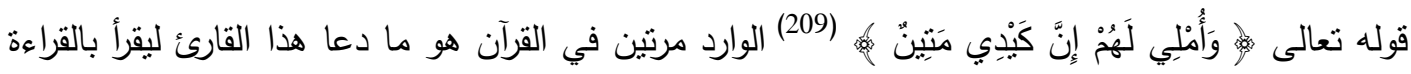
السابقة ولا تخلو هذه القرلاءة من الأثر التفسيري لها. 


\section{خاتمة البحث}

مجلــــة كليــــة التربيـــة

فرّق القدماء بين همزتي القطع والوصل وبين حركاتهما ؛ فالمتقدّمون كانوا يشيرون إلى الهمزة (همزة

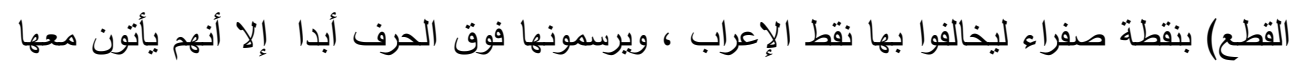

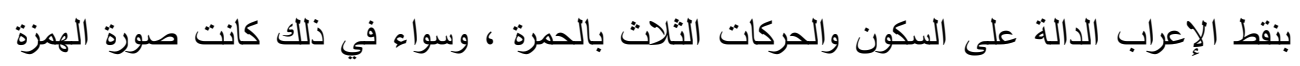

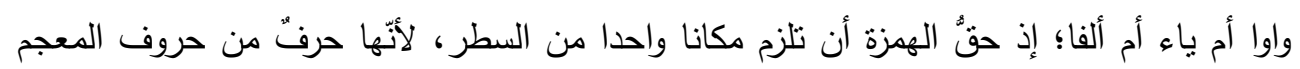

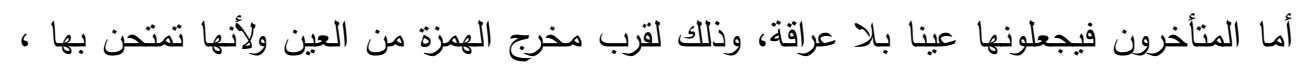

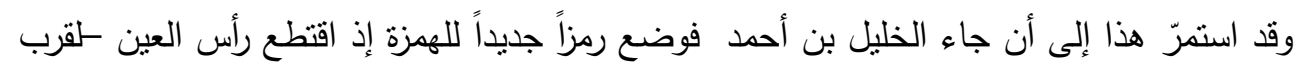

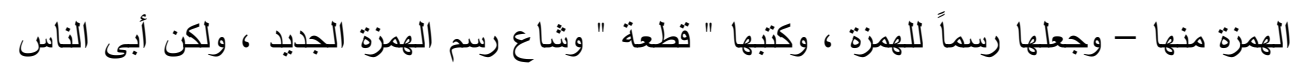

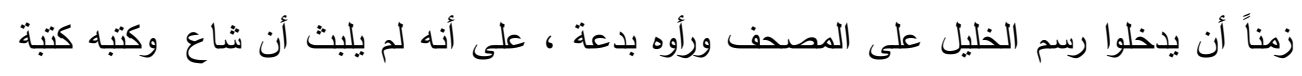

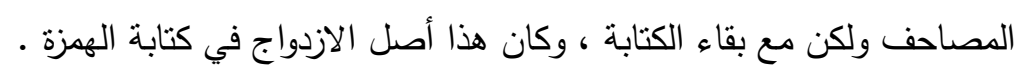

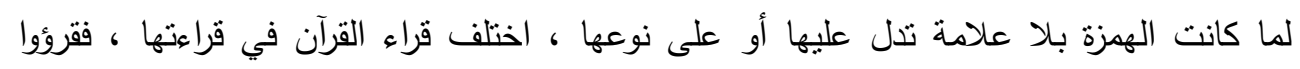

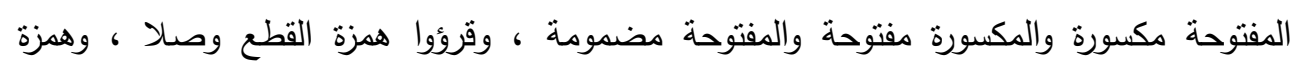

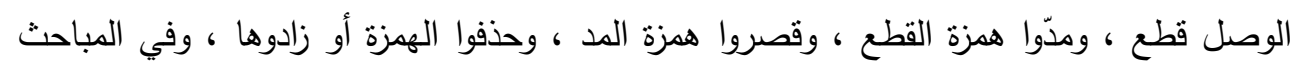

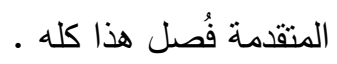
لما كانت الهمزة ترسم في بداية الأمر على شكل ألف ، ولم تكن ثمة علامة لها ، اختلف القرّاء في

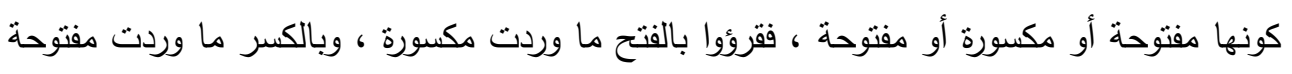

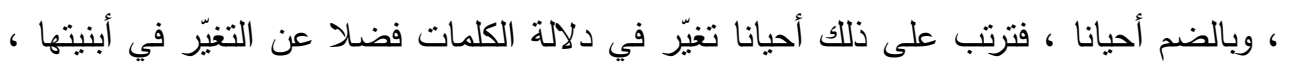

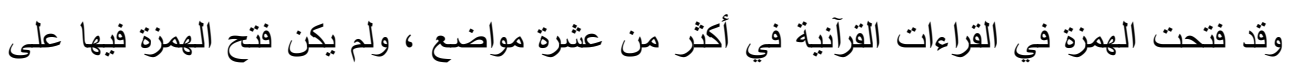

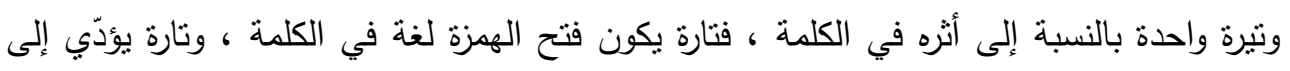

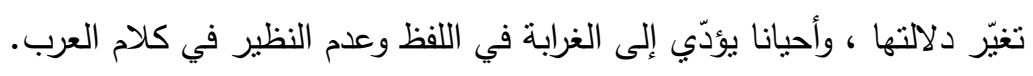

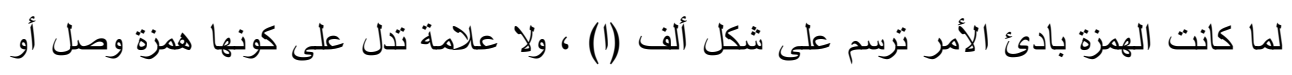

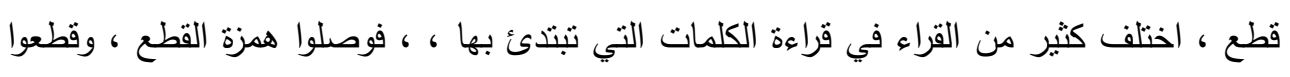

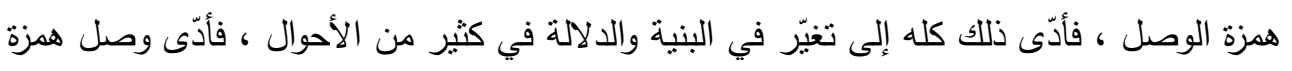

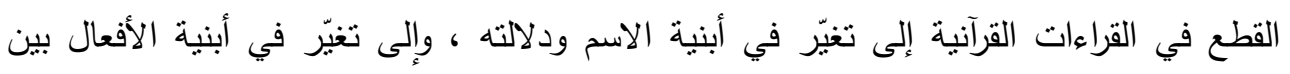

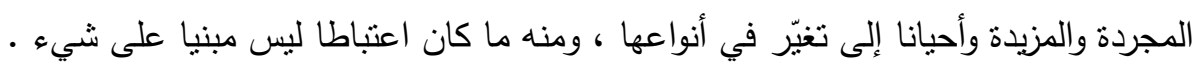




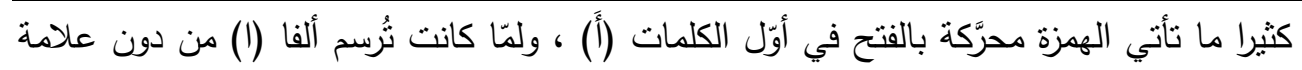

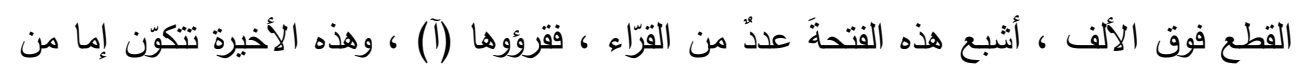

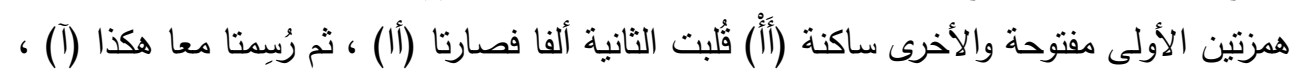

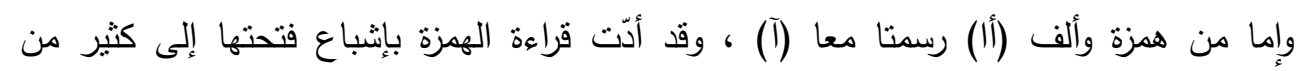

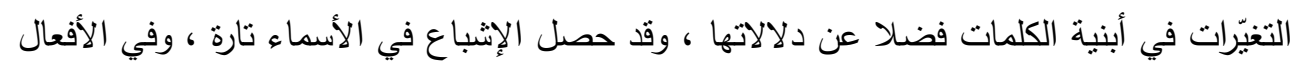

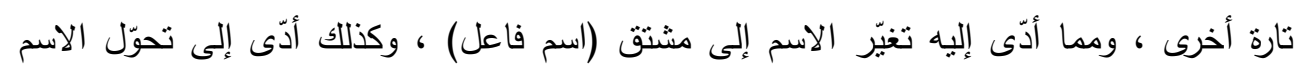

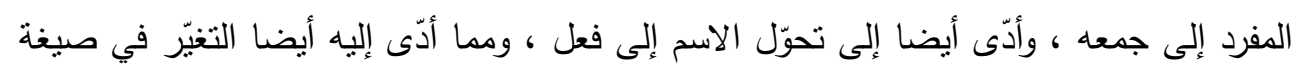

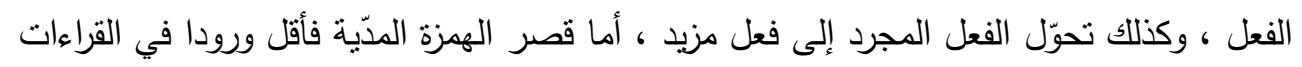

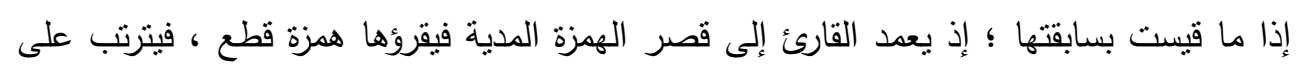

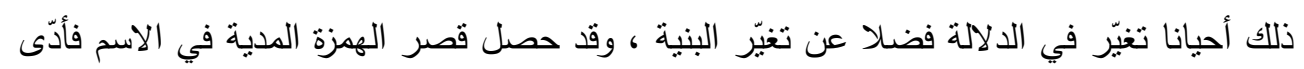

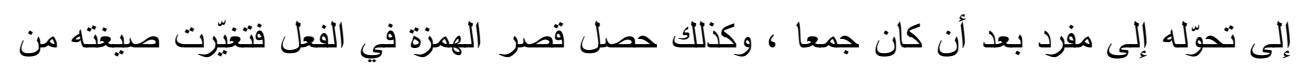

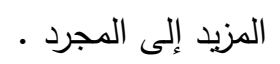

حُذفت الهمزة في عدد من القراءات القرآنية وزيدت في عدد آخر ، والسبب يرجع في إلى أن هذه

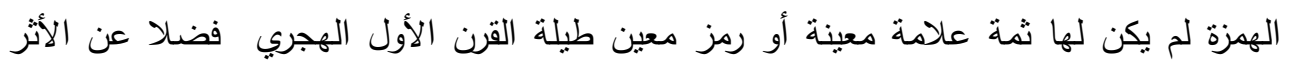

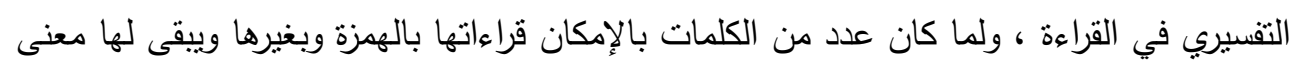

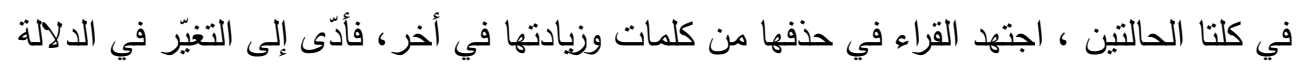

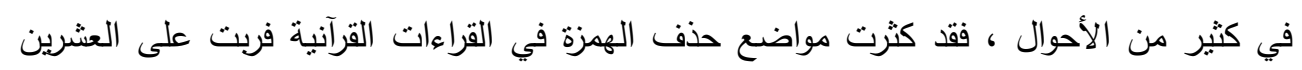

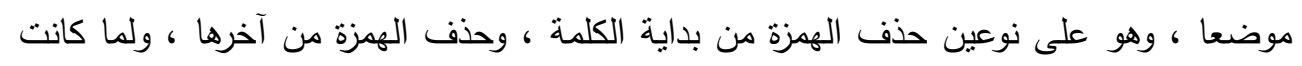

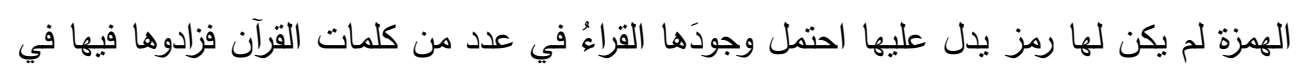
قراءاتهم ، وهذه الزيادة على نوعين : زيادة في أول الكلمة وزيادة في آخرها:

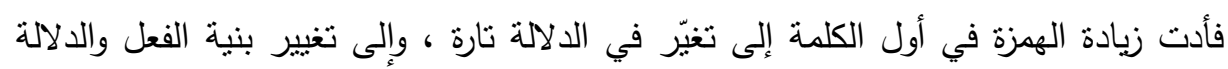

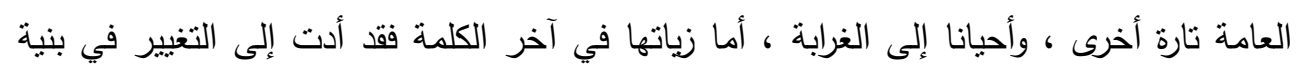

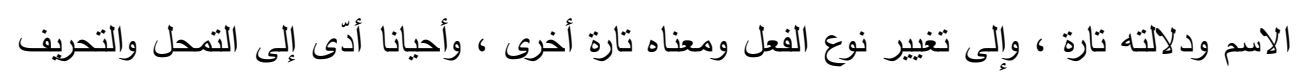

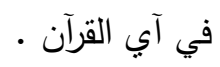


1 ينظر : الخطوالكتابة في الحضارة العربية ، 22 ، وينظر مشكلة الهمزة العربية : 11 ، وينظر أثز صوت الهمزة

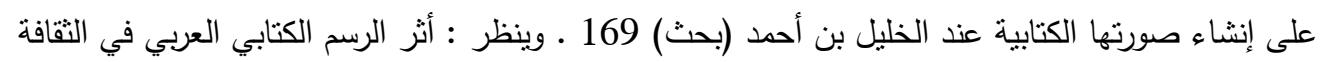

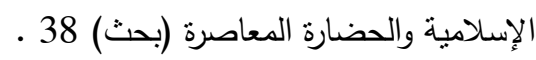

2 ينظر : أخبار النحويين البصريين ، 13 . 13

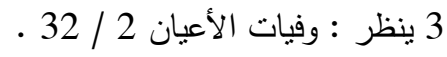

4 ينظر : المصدر نفسه 1 / 172 ـ 172

5 ينظر : المحكم في نقط المصاحف ، 52 . 52 .

6 ينظر أثر صوت الهمزة على إنثاء صورتها الكتابية عند الخليل بن أحمد (بحث) 199 ـ 192

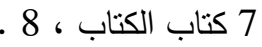

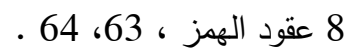

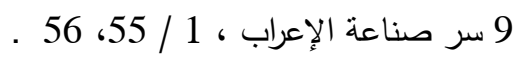

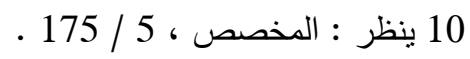

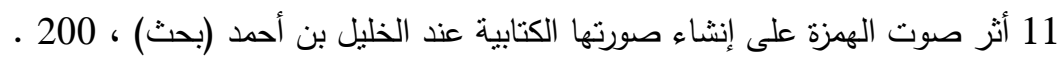

12 شرح الثافية ، 3 / 32 ـ 32

13 ينظر : سنن النزمذي 1 / 439 ـ 432

14 ينظر : أثز صوت الهمزة على إنثاء صورتها الكتابية 203 ـ 239

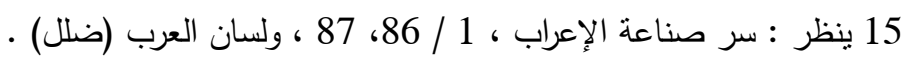

16 ينظر : الخصائص 3 / 134

71 : 17

18 ينظر المُحنَّبَ : 1/ 434 ، ومعاني القرآن للأخفش : 346/2 ، وإعراب القرآن للنحاس : 67/2 .

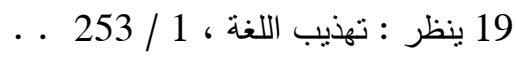

20 المخصص 4 / 343.

21 سورة البقرة ، الآية 126 ـ

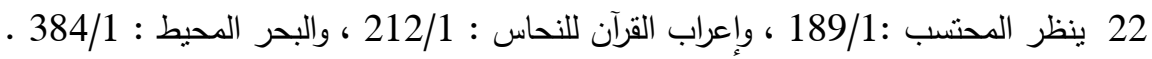

23 سورة البقرة : من الآية 126

24 سورة البقرة : من الآية 126 
مجلــــة كليــــة التربيـــة

25 سورة البقرة : من الآية 126

26 المُحتَسَب : 11 / 189.

27 سورة النساء : الآية 26

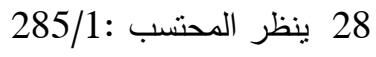

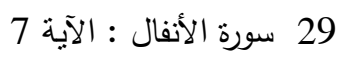

30 ينظر المُحتَسَب : 13 / 387 سورة الأفال : 38

31 سورة التوبة : الآية 52

32 ينظر المُحتَسَب : 1312

33 سورة القصص : الآية 25

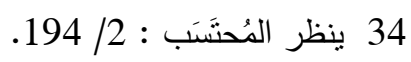

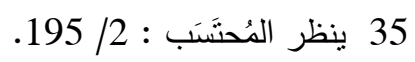

36 سورة الكهف : الآية 35

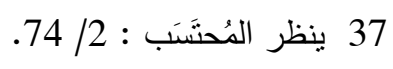

38 38 المُحسَّبَ : 34

39 سورة الرحمن : الآية 54

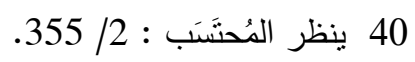

41 المُحتَسَب : 40

42 سورة الأنبياء : الآية 412

43 ينظر المُحتَسَب : / / ل 42

114/2: 44

45 سورة إبراهيم : الآية 35

46 ينظر معاني القرآن للفراء : 78/2 ، والمُحنَسَب : 38/2 ، 38/2 ، والكثاف : 379/2.

38/2: 47

48 سورة يس : الآية 19

49 ينظر المُحتَسَب : 250 / 250 ، والكثاف : 318/3 ، والبحر المحيط :327/7 ـ.

50

51 سورة فصلت : الآية 44 
52 ينظر معاني القرآن للفراء : 19/3 ، والمُحتَسَب : 295 / 295 ، والنشر في القراءات العشر : 366/1 .

53

54

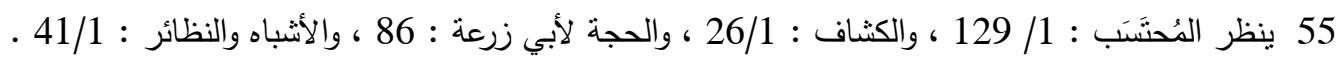

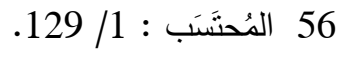

57 كتاب سيبويه : 3 / 58 / 58 : 58

58 سورة يس : الآية 10

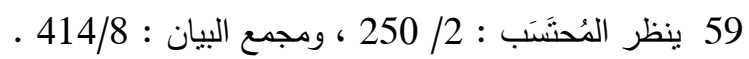

60

61 سورة المنافقون : الآية 62

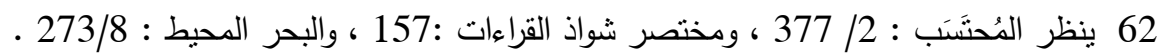

63 المُحتَسَب : 62

64 سورة الزخرف : الآية 19

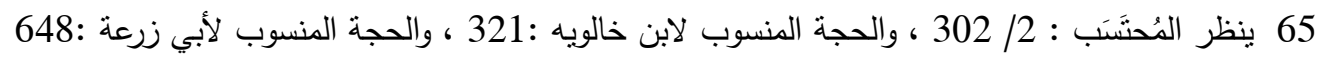

66 سورة فصلت : الآية 64

67 ينظر معاني القرآن للفراء : 19/3 ، والمُحنَسَب :2/7 / 295، ومختصر شواذ القراءات : 133 ، والبحر المحيط . 502/7:

68

69 المُحَسَب : 186

70 70 سورة الحجر : الآية 44

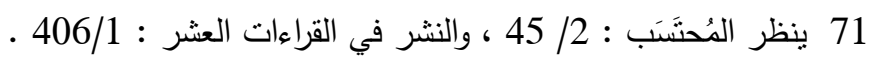

72 ينظر المُحنَسَب : 72

73 سورة النحل : الآية 5

74 ينظر المُحسََبَ : 79 / 49 ، والبحر المحيط : 475/5 .

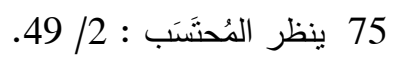

76 سورة البقرة : الآية 102

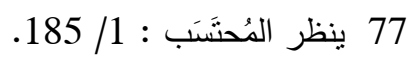




\section{8 المُحتَسَب : 186 \\ 79 سورة الأنفال : الآية 24}

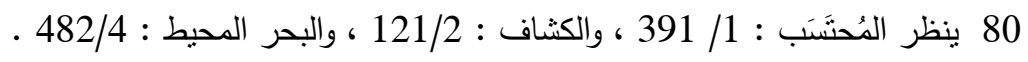
81

82 سورة الأنفال : الآية 11 ليطر 11

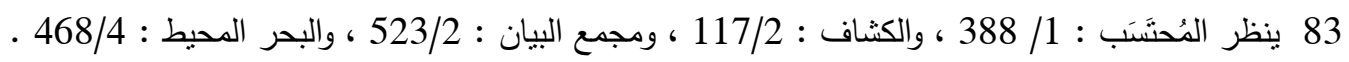

84

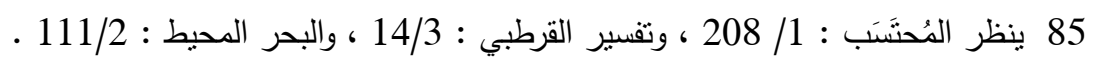

86 سورة البقرة : الآية 853

87 المُحتَسَب : 809

88 ينظر : الخصائص : 187 / 8 / 828

89 سورة عبس : الآية 22

90

91 سورة عبس : الآية 1 ، 2 . 2 . 92

92 ينظر المُحتَسَب : 416 / 416 ، ومختصر شواذ القراءات 169 ، و و وإتحاف فضلاء البشر :433 ، ومجمع البيان : . 436/10

93 المصطلح الذي يرتضيه الباحثان هو (إثباع حركة الهمزة) ، ولكن أُثبت المصطلح أعلاه تجوزا .

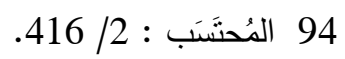

95 سورة الانفطار : الآية 64

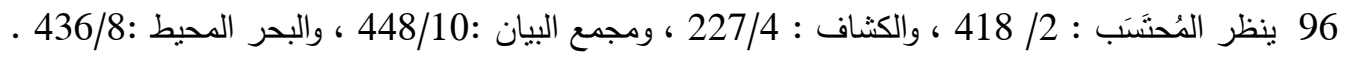

97

98 المُحتََّب : 918 : 40

99

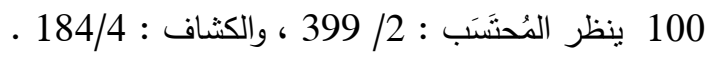

101

102 سورة النور : الآية 103

103 ينظر المُحتَّب : 102 / 157 ، وتفسير القرطبي : 290/12 ، وتفسير الرازي : 15/24 . 


$$
\begin{aligned}
& 104 \text { ينظر معانيها لسان العرب (سنا ) . } \\
& 105 \text { كذا في المحتسب ، وفي المعجمات (السنا) . } \\
& 106 \text { المُحتَسَب : } 105 \\
& 107 \text { سورة القدر : الآيتان } 4 \text { ، } 5
\end{aligned}
$$

108 ينظر معاني القرآن للفراء : 280/3 ، والمُحتَسَب : 2 / 436 ، ومختصر شواذ القراءات : 177 .

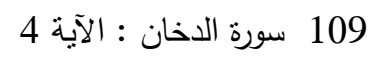

110

111 سورة التغابن : الآية 11

112 ينظر المُحتَسَب : 279 / 379 ، ومختصر شواذ القراءات :158 ، والكثاف : 115/4 ، والبحر المحيط :

113 سورة آل عمران: الآية 18

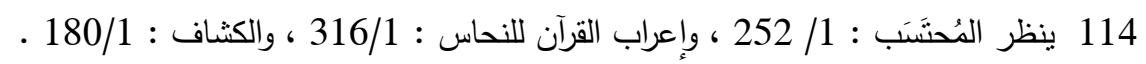

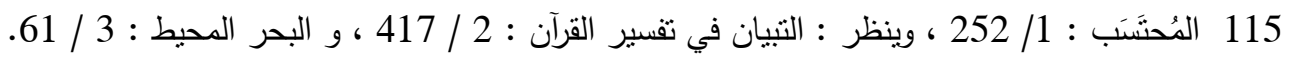

116 ينظر الصحاح : (أفلك).

117 سورة الأعراف : الآية34 116

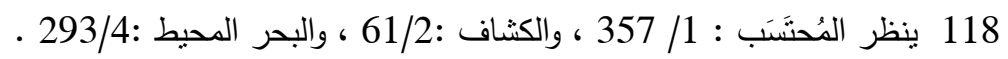

$$
\begin{aligned}
& 119 \text { سورة الأحقاف : الآية } 28
\end{aligned}
$$

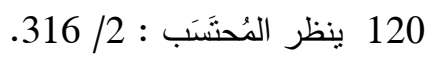

$$
\begin{aligned}
& 121 \text { المُحسَسَب : } 120 \\
& 122 \text { سورة البقرة : الآية } 87
\end{aligned}
$$

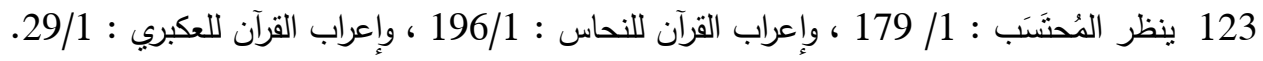

124

125 سورة الإسراء : الآية 124

126 ينظر معاني القرآن للفراء : 119/2 والمُحتَسَب : 2 م 60 ، وتفسير الطبري : 42/15 .

127 سورة الطور : الآية 21 سبطن

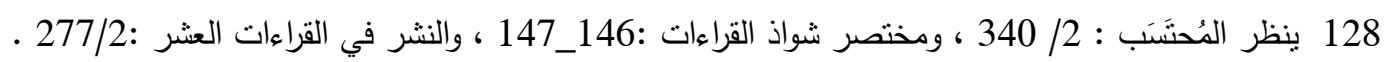

129 
130

131 ينظر جمهرة اللغة : (ألت).

132 ينظر الصحاح : (ألت).

133 النهاية في غريب الحديث والأثر 1 / 134

134 سورة المنافقون: الآية 6

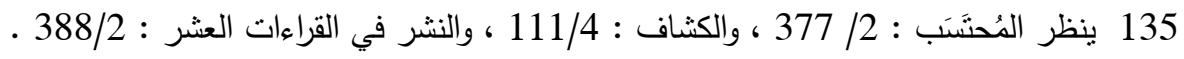

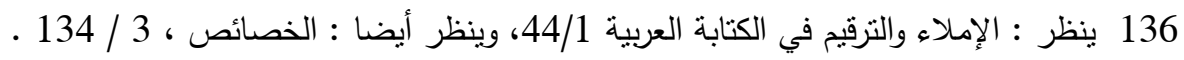

137 سورة البقرة: 80 .

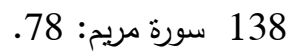

139 سورة سبأ: 8.

140 سورة الصافات 153 ـ

141 سورة ص: 142

142 سورة ص:75.

143 سورة المنافقون: 6.

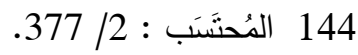

145 التبيان في إعراب القرآن : 2 / 208 / 274

146 سورة الروم: الآية 9

147 ينظر المُحتَّبَ : 146 الابة 206.

148 ينظر المصدر نفسه والجزء والصفحة أنفسهما .

149 سورة البقرة: الآية 71

150 المُحَتَّب : 149 / 206 ، وينظر الخصائص : 3 / 126 / 126 ـ

151

152 سورة الروم: الآية 50

153 ينظر معاني القرآن للفراء : 326/2 ، والمُحتَسَب : 2 / 208 ، والحجة المنسوب لابن خالويه : 283 ، 2

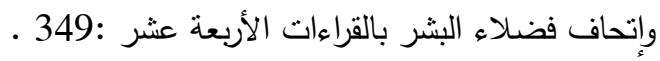

154 سورة المؤمنون: الآية 60

155 ينظر معاني القرآن للفراء : 238/2 ، والمُحسَسَبَ : 254 / 138 ، وتفسير الرازي : 23 / 107 . 


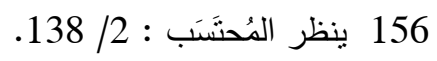

157

158 سورة الفاتحة : الآية 5

159 ينظر المُحسَّبَ :1 114

160

161

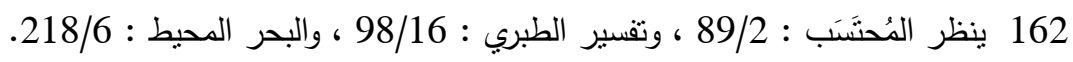

163 المصدر نفسه والجزء والصفحة أنفسهما .

164 ينظر جمهرة اللغة (أدد) . 163

165 ينظر مجمل اللغة (أد) . 166

166 ينظر الصحاح (أدد) .

167 سورة العنكبوت : الآية 168

168 ينظر المُحنَسَب : 169

169 سورة الواقعة : الآية 15

170

171 سورة الأحقاف : الآية 28

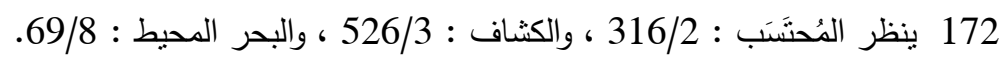

173

174

175 ينظر المُحنَّب : 342/2 ، ومجمع البيان : 169/9 ، وتفسير القرطبي : 80/17 .

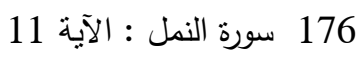

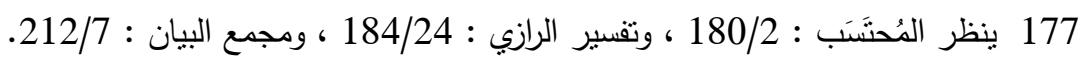

178 سورة النساء : الآية104 الفئن

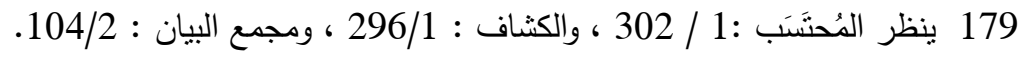

180 المصدر نفسه والجزء والصفحة أنفسهما .

181 سورة الأحزاب : الآية 50

182 ينظر المُحتَسَب : 225/2، والكثاف : 268/3 الأن ، والبحر المحيط : 242/7. 


$$
\begin{aligned}
& 183 \text { المصدر نفسه :226/2 . } \\
& 184 \text { سورة يونس : الآية } 4 \\
& 185 \text { ينظر المُحتََبَ : } 186
\end{aligned}
$$

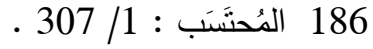

$$
\begin{aligned}
& 187 \text { سورة آل عمران : الآية } 3 \\
& 188 \text { ينظر المُحتَسَب : } 1897 \text { / } 247 \text { ، و } 2 \text { / } 2464 . \\
& 189 \text { المصدر نفسه 1/ } 247 \text { ـ } 248 \\
& 190 \text { سورة الأعراف : الآية } 187 \\
& 191 \text { سورة النحل : الآية } 21 \\
& 192 \text { سورة الذاريات : الآية } 12
\end{aligned}
$$

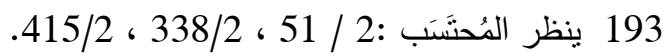

$$
\begin{aligned}
& 194 \text { ينظر المُحتَسَب :2 } 193 \\
& 195 \text { سورة يوسف : الآية } 45 \\
& 196 \text { ينظر المُحتَسَب : } 196 \\
& 197 \text { التهذيب : (أمم). }
\end{aligned}
$$

199 ينظر المحتسب :362/2 ، وتفسير القرطبي : 243/17 ، والبدة البحر المحيط : 221/8 ـ

203 ينظر المُحتَسَب : 312/1، ومعاني القرآن للفراء : 229/1 ، وتفسير الطبري : 485/5 ، والكثاف : 1/ 321

204

205

321/2: 206

207 المصدر نفسه والجزء والصفحة أنفسهما . 208

208 ينظر تاج العروس : (أمل) . 
209 سورة الأعراف : الآية 183 ، و سورة القلم : الآية 45.

مصادر البحث

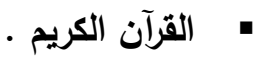

• إتحاف فضلاء البشر في القراءات الأربع عشرة ، أحمد الدمياطي البنّا، مطبعة عبد الحميد حنفي

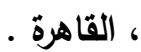

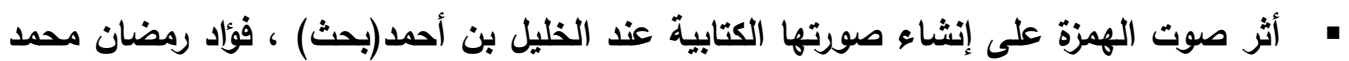

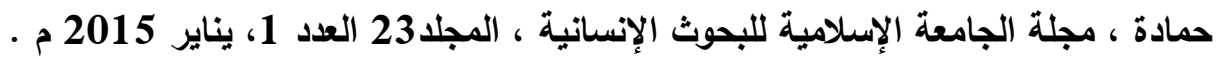

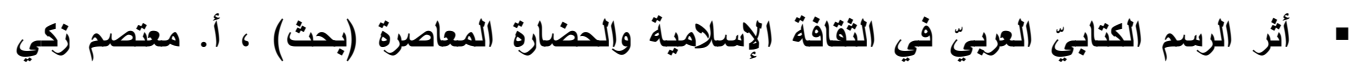

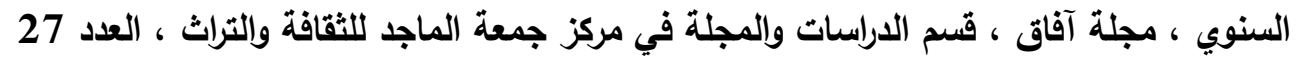

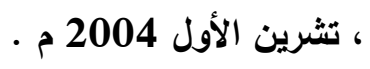

• أخبار النحويين البصريين ، السيرافي ، تحقيق طه محمد الزيني ، محمد عبد المنعم الخفاجي ،

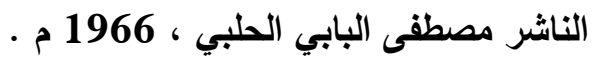
إعراب القرآن ، أبو جعفر النحّاس ، تحقيق الدكتور زهير غازي زاهـ ، ، مطبعة العانيّ ، بذاد ، 1977م إع 1987 الإملاء والترقيم في الكتابة العربية ، عبد العليم إبراهيم (المتوفى: بعد 1395هـ) ، مكتبة غريب، مصر البحر المحيط ، أبو حيّان التوحيديّ ، مكتبة النصر الحديثة ، الرياض .

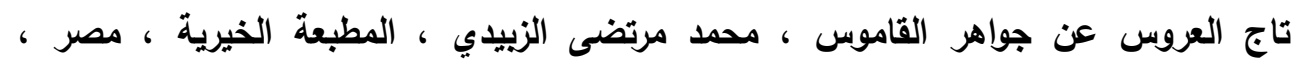

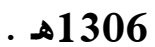
التفسير الكبير ، الفخر الرازيّ ، مصر ، ط1 ، 1935م.

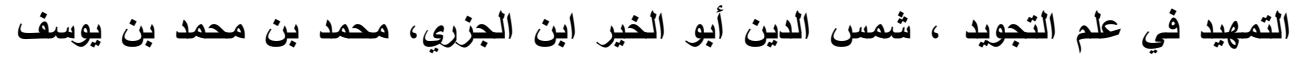
(المتوفى: 833هـ) تحقيق: الدكتور على حسين البواب ، مكتبة المعارف، الرياض الطبعة:

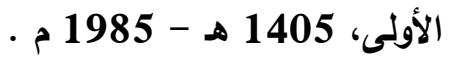
• تهذيب اللغة ، محد بن أحمد بن الأزهري الهروي، أبو منصور ، تحقيق: محمد عوض مرعب ،

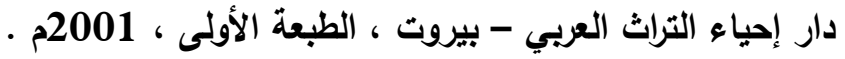


• جامع البيان عن تأويل آي القرآن ، الطبريّ ، مطبعة البابى الحلبيّ ، ط2، 1954م.

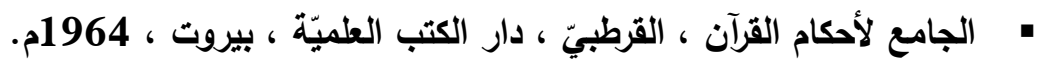

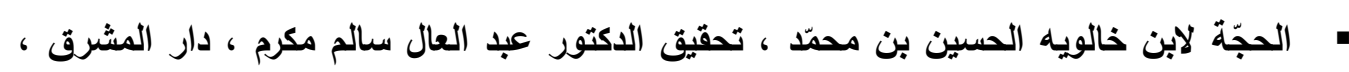
بيروت ، 1977م.

الخصائص ، ابن جني ، تحقيق محمد علي النجار ، دار الثؤون الثقافية العامة ، بذداد ، - 1990 الخط وإكتابة في الحضارة العربية ، الدكتور يحيى وهيب الجبوري ، دار الغرب العربي ، الطبعة

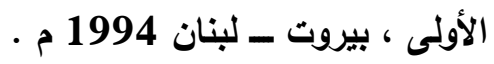
• دراسات في علم اللغة ، الدكتور كمال محمد بشر ، دار المعارف ، مصر ، الطبعة التاسعة ، 1986 روح المعاني في تفسير القرآن العظيم والسبع المثاني ، شهاب الدين محمود ابن عبدالله

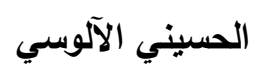

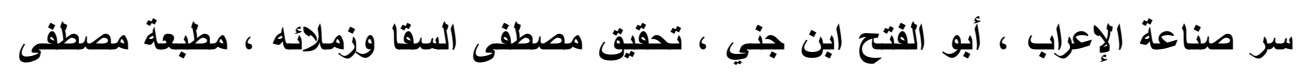

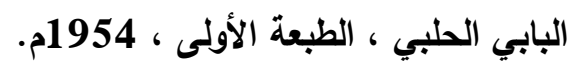

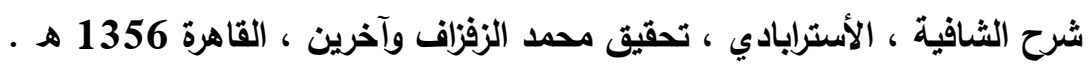

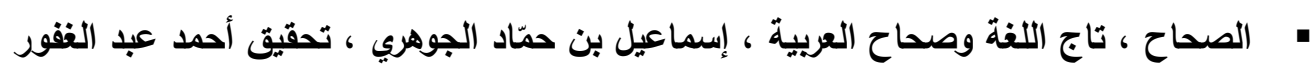

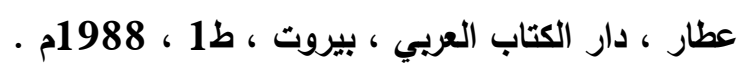

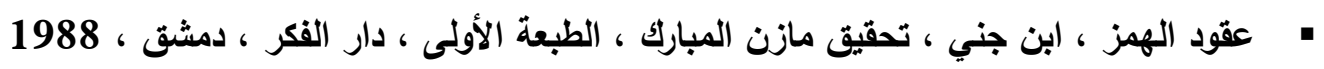
• كتاب الكتاب ، ابن درستويه ، تحقيق إبراهيم السامرائي وعبد الحسين الفتلي الكويت ، 1977 م

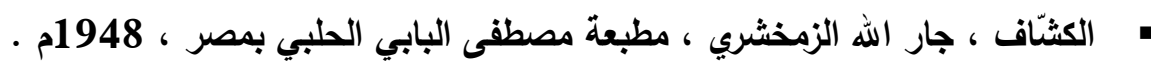

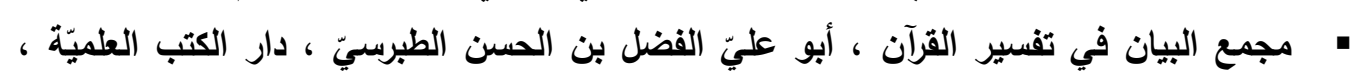

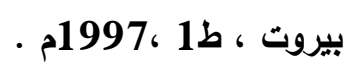




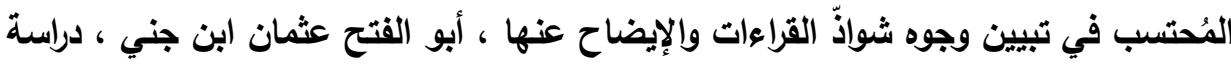

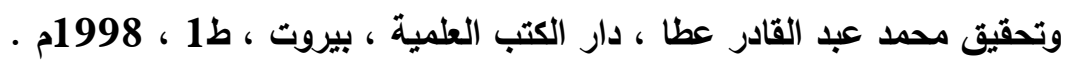

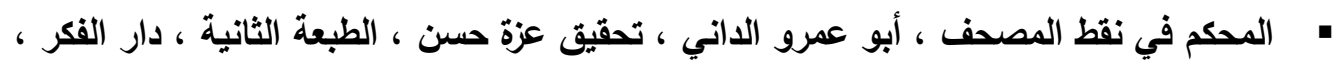
1997 م م.

• مختصر في شواذّ القراءات ، ابن خالويه ، تحقيق برجستراسر ، المطبعة الرحمانية بمصر ، • 1934

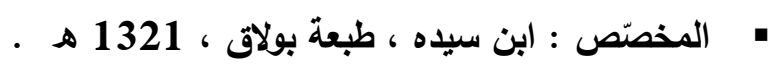
• مشكلة الهمزة العربية ، الدكتور رمضان عبد التواب ، مطبعة المدني ، الطبعة الأولى ، 1321 ، 1996 م

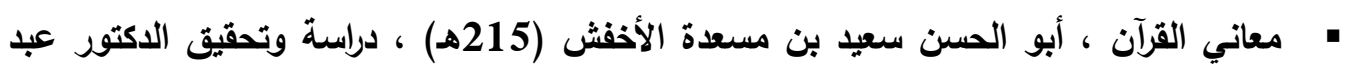

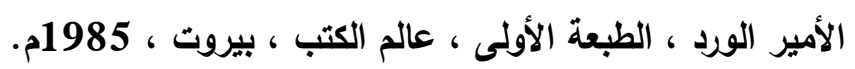

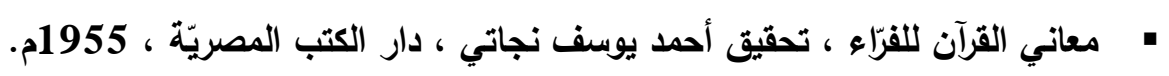

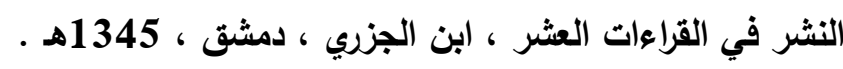

